Review

\title{
Sharka: The Past, The Present and The Future
}

\author{
Jiri Sochor ${ }^{1,2,3}$, Petr Babula ${ }^{1,2,3}$, Vojtech Adam ${ }^{1,3}$, Boris Krska ${ }^{4}$ and Rene Kizek ${ }^{1,3 *}$
}

1 Department of Chemistry and Biochemistry, Faculty of Agronomy, Mendel University in Brno, Zemedelska 1, CZ-613 00 Brno, Czech Republic; E-Mails: sochor.jirik@seznam.cz (J.S.); petr_babula@email.cz (P.B.); vojtech.adam@mendelu.cz (V.A.); kizek@sci.muni.cz (R.K.) Department of Natural Drugs, Faculty of Pharmacy, University of Veterinary and Pharmaceutical Sciences Brno, Palackeho 1-3, CZ-612 42, Czech Republic

3 Central European Institute of Technology, Brno University of Technology, Technicka 3058/10, CZ61600 Brno, Czech Republic

4 Department of Fruit Growing, Faculty of Horticulture, Mendel University in Brno, Valticka 337, CZ-691 44 Lednice, Czech Republic; E-Mail: krska@zf.mendelu.cz

* Author to whom correspondence should be addressed; E-Mail: kizek@sci.muni.cz; Tel.: +420-5-4513-3350; Fax: +420-5-4521-2044.

Received: 15 October 2012; in revised form: 25 October 2012 / Accepted: 30 October 2012 / Published: 7 November 2012

\begin{abstract}
Members the Potyviridae family belong to a group of plant viruses that are causing devastating plant diseases with a significant impact on agronomy and economics. Plum pox virus (PPV), as a causative agent of sharka disease, is widely discussed. The understanding of the molecular biology of potyviruses including PPV and the function of individual proteins as products of genome expression are quite necessary for the proposal the new antiviral strategies. This review brings to view the members of Potyviridae family with respect to plum pox virus. The genome of potyviruses is discussed with respect to protein products of its expression and their function. Plum pox virus distribution, genome organization, transmission and biochemical changes in infected plants are introduced. In addition, techniques used in PPV detection are accentuated and discussed, especially with respect to new modern techniques of nucleic acids isolation, based on the nanotechnological approach. Finally, perspectives on the future of possibilities for nanotechnology application in PPV determination/identification are outlined.
\end{abstract}


Keywords: viruses; plant; Potyviridae; plum pox virus; sharka; polymerase chain reaction; immune detection; ELISA; nanotechnology

\section{Introduction}

Sharka or pox or plum pox disease is one of the most devastating viral diseases of stone fruits, with a significant impact on agronomy and economics. The disease is caused by plum pox virus (PPV), a member of Potyvirus genus in Potyviridae family. It is able to damage not only plums (especially Prunus domestica L.) [1,2], but also apricots (Prunus armeniaca L.), peaches (Prunus persica (L.) Batsch.) [3], nectarines (Prunus persica var. nucipersica (Borkh.) C.K. Schneid., hybrids) [4], almonds (Prunus dulcis (Mill.) D. A. Webb, syn. P. amygdalus (L.) Batsch., Amygdalus communis L., Amygdalus dulcis Mill.) [5-7], sweet cherries (Prunus avium (L.)) [8,9] and tart cherries (Prunus cerasus L.) [10-12]. PPV is able to infect also important ornamental and wild Prunus L species, including those used in traditional medicine: myrobalan (P. cerasifera Ehrh.) [13-15], American plum (P. americana Marsh.) [16,17], dwarf flowering almond (P. glandulosa Thunb.) [18,19], and blackthorn (P. spinosa L.) [17,20-22]. In addition, almost 60 species in eight families have been recognized as experimental host plants [23-27]. Nevertheless, plum pox virus is able to infect naturally occurring plants, which are not members of genus Prunus. Infected walnut trees (Juglans regia L.) were reported in Slovakia in 1996 by Baumgartnerova [28]. This information was based on the presence of diffuse spots on the leaves of infected plants. Despite the fact that PPV infection was detected by ELISA and the virus transmitted to the host plants, the presence of PPV-infected Juglans regia trees was not later confirmed, see Polak [29]. On the other hand, ELISA, ISEM and biological tests confirmed presence of PPV in Euonymus europae L. (Celastraceae R. Br.) and Ligustrum vulgare L. (Oleaceae Hffg. et Link) [29]. PPV is one of the most important members of family Potyviridae and the results of the infection are shown in Figures 1A-D. Family Potyviridae includes flexuous filamentous rod-shaped viruses of lengths of 650-950 nm and diameter of 12-15 nm, more exactly ssRNA non-encapsulated viruses with almost one-third plant viruses. The family includes seven genera as Brambyvirus, Bymovirus, Ipomovirus, Macluravirus, Potyvirus, Rymovirus and Tritimovirus. The most important members, their characteristics including vector(s), host plant(s) and distribution have been summarized in a plenty of extensive reviews, such as Gibbs and Ohshima [30], Gibbs et al. [31], Revers et al. [32], Riechmann et al. [33], and Ward and Shukla [34].

Potyviruses are transmitted predominantly by insects. Genera Potyvirus and Macluravirus are transmitted by aphids (Aphis Linnaeus, Brachycaudus van der Goot, Brevicoryne van der Goot, Macrosiphum Passerini, Myzus Passerini, Phorodon Passerini, and Rhopalosiphum Koch) [35-38]. In addition, eriophyid mites spread members of Rymovirus and Tritimovirus (Abacarus Keifer, Aceria Keifer) [39-41] and whiteflies (Bemicia Quaintance et Baker) spread members of Ipomovirus [42-44]. Only members of Bymovirus are transmitted by plasmodiophoroid fungus (Polymyxa graminis Ledingham, Plasmodiophoridae) [45-48]. It has been established that potyviruses are generally transmitted by non-circulative manner, which means that virus articles do not cross the vector cell membranes. However, not all potyviruses require specific associations with aphids. This exception is 
represented by Bymovirus, where species are restricted to Poaceae (Graminae) and are transmitted in soil by zoospores of Polymyxa graminis Ledingham. In this case, it is very difficult to study the epidemiology of diseases caused by Bymovirus, because they are not transmitted mechanically, purified preparations demonstrate only low infectivity, and the vector is an obligate parasite of roots that inhabits the individual cells of rhizodermis and cortex [49]. In addition, they frequently occur in a mixture with furoviruses. A new soilborne virus - soybean leaf rugose mosaic virus (SLRMV) - has been isolated and characterized by Kuroda et al. [50]. This virus is closely related to bymoviruses, however, further characterization is necessary. However, Polymyxa graminis is obligate parasite of monocot plants (Glycine max (L.) Merr. is dicot) and soybeans became diseased when grown in virusinfested soil [50]. With exception of Bymovirus with bipartite genome, where open reading frame is divided between two genomic RNAs, all potyviruses have monopartite genome with a genome-linked protein attached to the $5^{\prime}$ end (VPg) and a polyadenosine tail at the $3^{\prime}$ end of the genome. Their genome was characterised also as monocistronic for many years because of the presence of only one functional ORF. However, bioinformatic evidence and experimental verification of the evidence for overlapping coding sequences within the P3 cistron of potyviruses have been presented in the work of Chung et al. in 2008 [51].

Figure 1. (A) Peach blossoms showing typical speckling of Plum Pox infected trees. Note the darker pink stripes on petals. (B) Chlorotic rings and blotches develop in peach leaves. (C) Yellow rings on a yellow-fleshed peach cultivar. (D) Ring patterns visible on the pit of an apricot.
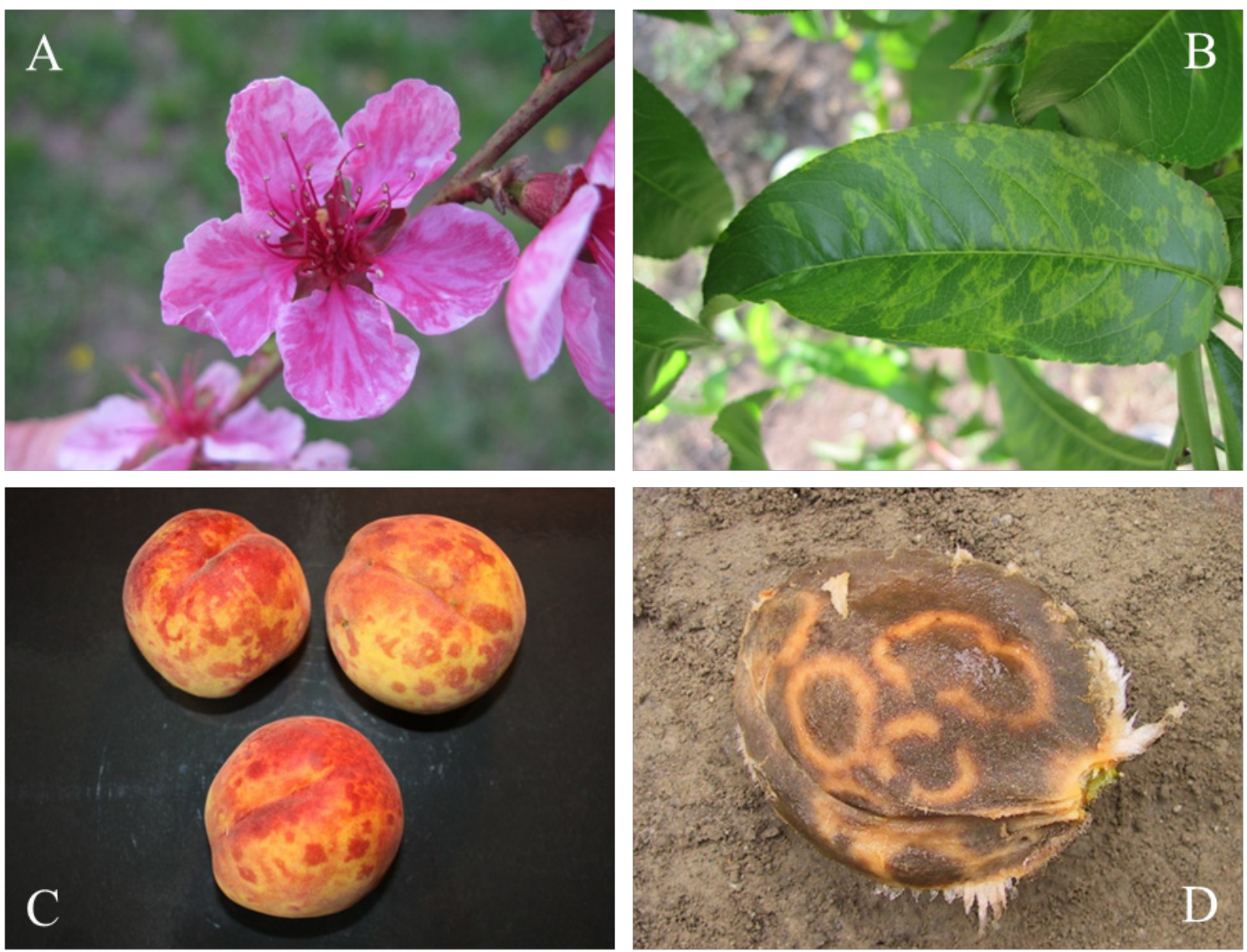
In a Turnip mosaic virus, pipo (Pretty Interesting Potyviridae ORF) consists of 60 codons in the +2 reading frame relative to polyprotein, which places it within the $\mathrm{P} 3$ cistron. Disruption of pipo leads to the no changes in the polyprotein amino acid sequence; however, these mutants are not able to establish systemic infection. The ability of pipo mutants to establish systemic infection is still being discussed. Whereas Wen and Hajimorad in their mutational analysis of the putative pipo of soybean mosaic virus suggested that the disruption of PIPO protein impedes movement [52], the same authors together with Maroof later established that not PIPO but P3 is responsible for the changes in the virulence of the soybean mosaic virus [53]. A cap-independent translation is mediated by the 5'UTR [54]. The genome is expressed as a single polypeptide (polyprotein) precursor, which is proteolytically processed to mature virus proteins. However, due to fact that pipo that is predicted to encode a $7 \mathrm{kDa}$ protein was discovered to overlap with the P3 coding regions in all potyviruses. Immunodetection of the pipo-encoded protein in Turnip mosaic virus infected cells revealed a $25 \mathrm{kDa}$ polypeptide, consistent with expression of pipo as a translational fusion with the $\mathrm{N}$-terminus of P3 [51]. This fact must be carefully considered in the characterization of potyviruses genome organisation. The potyvirus genome consists of a positive-sense single messenger-polarity RNA molecule of the size of about 10 $\mathrm{kb}$ (generally $8.5-12 \mathrm{~kb}$ ). The genome organization of potyviruses indicates nine cleavage sites and 11 mature proteins such as P1, HCpro, P3, P3N-PIPO, 6K1, CI, 6K2, NIa (respectively VPg and NIaPro), NIb and CP. In the light of above-mentioned fact, PIPO protein is expressed as a trans-frame protein consisting of the amino-terminal half of $\mathrm{P} 3$ fused to PIPO and a distinct C-terminus as a result of translational frameshift (P3N-PIPO). There are some exceptions in the potyviruses genome organisation [55]. Ipomovirus represents exception in the absence of HCpro and presence of two copies of $\mathrm{P} 1$ protein (P1a and $\mathrm{P} 1 \mathrm{~b})$, which is shown in Figure 2. The nascent polyprotein precursor is cleaved by three viral proteinases (they are endopeptidases) as P1 (P1/HCpro cleavage site, serine proteinase with cis-cleavage activity), HCpro (HCpro/P3 cleavage site, HCpro cysteine proteinase with cis-cleavage activity), and NIa, respectively C-terminal proteinase domain NIa-Pro (NIa-Pro cysteine proteinase, all other cleavage sites) [56]. Potyviruses encode specific nonstructural protein called helper component (HC) that is obligatory for virus transmission by aphids. Its role probably consists in binding both to virions and to the cuticular lining of aphid mouthparts with retaining the virions within the maxillary food canal of the aphid stylets. This short-term reversible binding is most likely necessary and sufficient for successful virus transmission from one plant to other plants. However, above-mentioned facts are hypothetical and they have been not fully demonstrated. Functional proteins are generated after action of virus-encoded proteases. P1 proteinase is located at the very beginning of the viral genome of potyviruses. Due to the fact that the serine-like peptidase domain in the P1 coding region was identified in the C-terminal, highly conserved portion for all serine peptidases, associated with proteolytic activity and containing the Gly-Xaa-Ser-Gly motif, P1 is serine peptidase [57]. It varies in the length as well as in an amino acid sequence [58]. P1 poses RNA-binding activity and the possible influence in cell-to-cell viral spreading. Its role in defining the host plant is studied too [59]. Work of Shi et al. that showed interactions between P1 proteinase of soybean mosaic virus and Rieske $\mathrm{Fe} / \mathrm{S}$ soybean protein are probably responsible for development of the symptoms of viral disease [60]. This N-terminal "hypervariable" protein is the most divergent protein among all potyviruses [61]. The Tritimovirus P1 functions as a suppressor of RNA silencing and an enhancer of disease symptoms were investigated by Young et al. [62]. However, P1 function must be further studied [63]. Potyviral 
helper component-proteinase (HCpro) has been recognized to be involved in the processes necessary for life, respectively infection cycle, especially in interactions with host proteins as well as other viral proteins. Thus, the presence of HC-pro is essential for all potyviruses [64]. These processes include not only interactions with host proteins, but also polyprotein processing and suppression of antiviral RNA silencing $[65,66]$. In addition, possible interactions between HCpro and host proteins must be carefully considered. This fact has been demonstrated in work of Shen et al., who observed interactions between HCpro and full-length papaya calcireticulin, the multifunctional protein that regulates intracellular calcium(II) ions levels and protein folding in the endoplasmic reticulum [67]. In conclusion, HCpro has multiple functions. Despite the HCpro multiple function, the understanding of its function is still poor. The work of Guo et al. revealed the crystal function of cysteine protease domain of HCpro from turnip mosaic virus [68]. HCpro cleavages only dipeptide Gly-Gly at its C terminus. A cleaved C domain remains tightly bond at the active site cleft to prevent trans activity. Generally, the structure adopts a compact alpha/beta-fold. The catalytic cysteine and histidine residues constitute an active site and HCpro recognizes a consensus sequence YXGVV around the cleavage site between two glycine residues [68]. There are at least six cleavage sites in cis-/trans-arrangement in the viral polyprotein recognized by NIa proteinase (NIa-Pro). NIa-Pro represents C-terminal domain of NIa and is shown to be analogous to picornavirus 3C protease [69]. The N-terminal domain of NIa is designated as VPg and will be further discussed. The active - catalytic - sites of NIa-Pro are defined by a consensus heptapeptide sequence surrounding each cleavage site containing triad of His-Asp-Cys, which are conserved among the potyviruses [70]. The mutation of the catalytic residues His46, Asp81, and Cys151 resulted in complete loss of activity [71]. In addition, NIa proteinase possesses structural motifs shared with cellular serine proteases with the substitution of serine by a cysteine as the active site nucleophile. The specificity of enzyme and control its activity is discussed in some recently published papers [72-74], which are focused on the investigation of recombinant viruses and their host interactions. Mutation in the Lys(27) of NIa-Pro has established the role of this enzyme in the determination of host specificity. On the other hand, Lys(27) mutation did not affect the protease activity of NIa-Pro [75]. The NIa-Pro is a sequence-specific proteinase required for processing of viral polyprotein in the cytoplasm. This fact has been demonstrated in many potyviruses, such as pepper vein banding virus (PVBV), and is generally relevant for all known potyviruses [76]. Its accumulation in nuclei of infected cells manifested as a formation of "inclusion bodies" and has been demonstrated in some papers, for example see work of Anindya et al. [71] or Restrepo et al. [77]. This fact has been established by Knuhtsen, who observed tobacco etch virus-induced intranuclear inclusions [78]. However, this author is not the first to demonstrate the presence of nuclear inclusions in the nuclei of infected cells. In 1968, Shepard used electron microscopy for the characterization of nuclear (and cytoplasmic as well) inclusions in tobacco etch virus-infected Nicotiana tabacum L. cv. Havana 425 [79], and before him in 1941, Sheffied observed formation of nuclear inclusions in infected cells [80]. The NIa-Pro nuclear localization is still investigated. Accumulation of Nia-Pro in nuclei is observable mainly at the end of viral infection cycle. It seems that NIa-Pro executes DNA cleavage activity, respectively nonspecific double-stranded DNA degradation. This fact indicates the NIa-Pro role in viral infection cycle with subsequent degradation of the host DNA [71]. Potential use of NIa-Pro in biotechnologies is indicated in the paper by Fellers et al., where three genes, each consisting of two NIa encoding regions (tobacco vein mottling virus, tobacco etch virus and potato virus Y) were 
introduced into Nicotiana tabacum L. cv. Burley 21. The authors indicate that "results of abovementioned paper showed that different potyvirus NIa-Pro genes can be used for a protection against potyvirus infection and may protect plants against more than one potyvirus" [81]. Generally, transformation of plants with translatable sequences corresponding to the structural proteins, such as $\mathrm{CP}$, or non-structural proteins such as the NIb or the P1 of potyviruses can make the plants highly resistant to infection with the corresponding virus [82-84]. Pathogen-derived resistance to viruses in transgenic plants is typically based on RNA silencing. This fundamental cytoplasmic antiviral defense system can be efficiently directed against viruses by producing homologous RNA from a transgene in plant cells.

Figure 2. Potyvirus genome. CP: capsid protein; P1: P1 proteinase; HC-pro: helper component proteinase; P3: protein P3; PIPO: protein; CI: cytoplasmic inclusion protein; Nia-VPg: viral genome-linked protein; NIa-Pro: nuclear inclusion protein a; Nib: nuclear inclusion protein N (RNA-directed RNA polymerase).

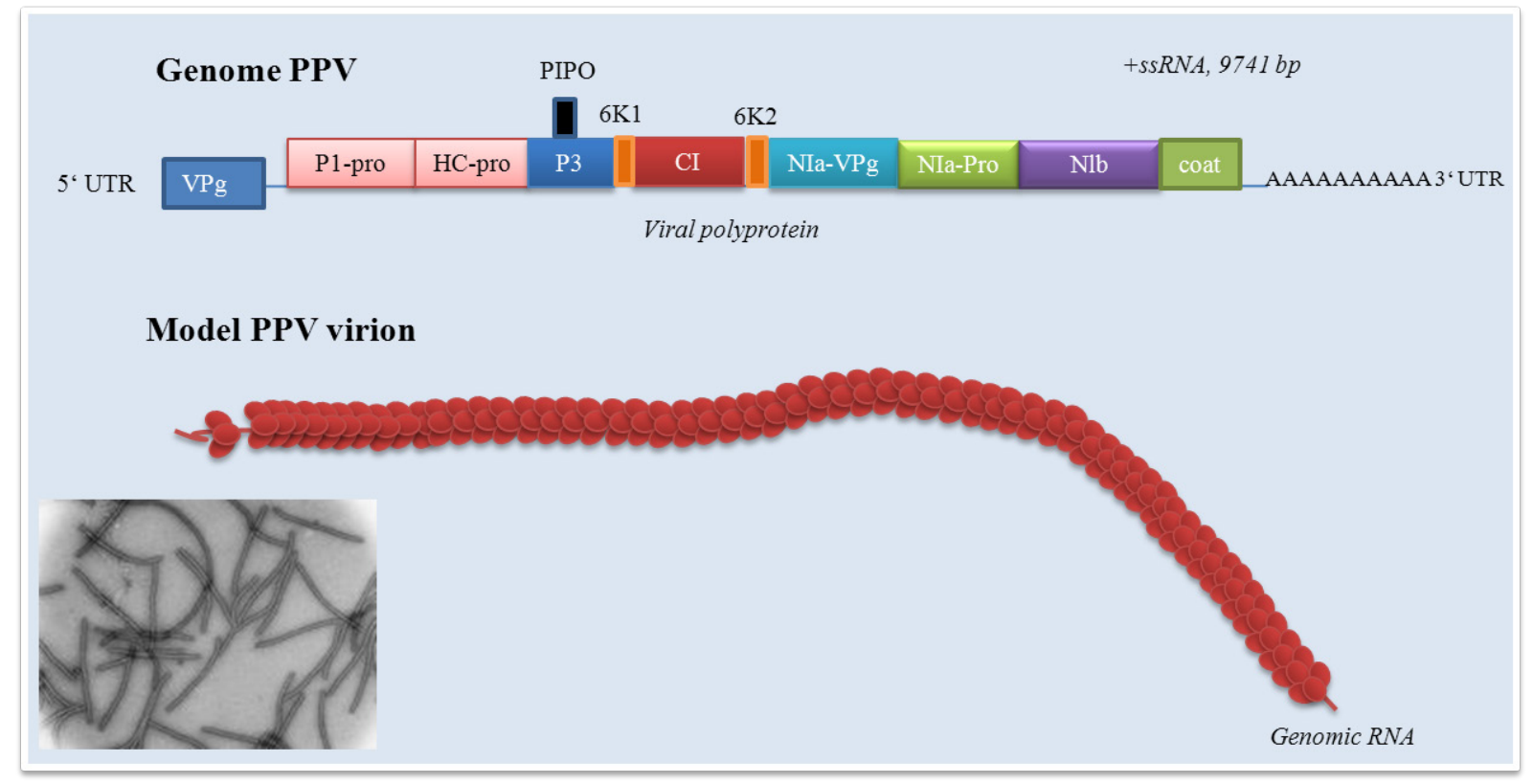

Plant potyviruses encode two membrane proteins $6 \mathrm{~K}$ and $\mathrm{P} 3$. The role of $\mathrm{P} 3$ protein is only poorly understood. The role of $\mathrm{P} 3$ in viral infection cycle and as a symptom determinant is shown in the paper by Jenner et al. [85]. Development of symptoms of the disease may be closely connected with interactions between the $\mathrm{P} 3$ protein and proteins of host plant. The paper by Lin et al. demonstrates the possibility of interactions between the $\mathrm{P} 3$ protein encoded by shallot yellow stripe virus onion isolate and small subunit of RubisCo (ribulose-1,5-bisphosphate carboxylase oxygenase), enzyme, which is essentially involved in carbon fixation [86]. Point mutagenesis in the P3 soybean mosaic virus proved its role in virulence in Rsv4 genotype soybean. A single amino acid substitution (Q1033K) in the P3 led to the resistance towards Rsv4-mediated resistance [87]. The P3 protein role in virulence was confirmed by recently published papers [88-91]. The study of Cui et al. was focused on determination of the P3 protein role in Nicotiana benthamiana Domin (Solanaceae) leaf cells infected by tobacco etch virus (TEV) [92]. Authors carried out TEV subcellular localization. The P3 protein was localized in endoplasmic reticulum and formed punctate inclusions in association with Golgi apparatus. These 
structures originated directly from the endoplasmic reticulum exit side. Localization of P3 (and, in addition P3-6K intermediate) in the endoplasmic reticulum was previously reported by Eiamtanasate et al. [93]. Finally, the P3 punctate structure was found to traffic along the actin filaments and colocalize with the W-containing replication vesicles. Deletion analyses demonstrated the irreplaceable role of P3 domains in the retention of the P3 at the Golgi [92]. The $6 \mathrm{~K} 1$ protein is generally quite insufficiently examined. In addition, data about its function is almost missing. The $6 \mathrm{~K} 1$ protein is probably responsible for the cell-to-cell movement. This fact may be confirmed by the paper by Hong et al., who observed the $6 \mathrm{~K} 1$ protein at the cell periphery of infected leaves of Pinellia ternata (Thunb.) Ten. ex Breitenb. (Araceae) [94] and the paper by Saenz et al., who determined 6K1 protein as the protein inducing viral replication vesicles [89]. However, the lack of a transmembrane domain suggests that it does not conform to recently recognized patterns of vital movement proteins [94]. The potyvirus cylindrical inclusion (CI) protein (or cylindrical inclusion helicase) represents a RNA helicase required for genome replication. The role of CI is discussed; however, this protein is necessary in facilitation cell-to-cell movement and replication. Tobacco etch virus (TEV) CI-mutants were replicationdefective in protoplast inoculation assay, some mutants possessed cell-to-cell or long distance defects in the paper by Carrington et al. [95]. Ultrastuctural analyses revealed interactions between the CI protein and plasmodesmata and capsid protein-containing ribonucleoprotein complexes to make cellto-cell and long-distance movement possible [96]. The presence of CI is connected with an apparent transient reduction in callose near the plasmodesmata [97]. Structural studies on Nicotiana benthamiana plants infected by plum pox virus revealed interactions between CI and the photosystem I PSI-K protein as the product of psaK gene. Coexpression of CI and PPV was shown to be responsible for a decrease of PSI-K accumulation as a result of psaK expression down-regulation. This effect is closely connected with PPV accumulation in $N$. benthamiana plants and confirms the role of CI in PPV infection [98]. In the recent papers, the role of CI in the breaking of resistance of plants against potyviruses is discussed [99]. The role of CI in the resistance against lettuce mosaic virus (LMV) is demonstrated in the paper by Tavert-Roudet et al. [100]. The C terminus of the CI together with VPg is directly involved in the overcoming mol, the gene responsible for recessive resistance of plants to lettuce mosaic virus, resistance. Mol gene encodes the eukaryotic translation initiation factor 4E (eIF $4 \mathrm{E}$ ). This factor is a component of the eIF $4 \mathrm{~F}$ complex and binds the cap structure of cellular mRNAs. Interactions between C-terminal part of the LMV CI and eIF 4E was proved [100]. However, further studies are necessary. Above-mentioned facts indicated the role of the viral protein linked to the genome (VPg), which represents the N-terminal domain of NIa. Its role, especially in resistant plants, is discussed in many published papers [101-104]. The VPg protein covalently links the 5' end of the viral RNA via tyrosine residue. The potato virus $A$ Vpg consists of 189 amino acids with a molecular mass of $21.9 \mathrm{kDa}$ [105]. Its model suggests an elongated structure with a hydrophobic core composed of antiparallel beta-sheets surrounded by helices and a positively charged contact surface where most of the known activities are localized [106]. This protein also acts important roles in viral life cycle and enables systemic invasion. The VPg protein accumulation in companion cells (cells closely associated with sieve tube members, phloem) of infected leaves at the beginning of the systemic infection indicates the VPg as a "phloem" protein and its role in facilitating the virus unloading [107]. However, the questions focused on role of phloem, respectively sieve tube members, in plant viruses longdistance transport, must be further discussed [108]. A single amino acid substitution (His118Tyr) in 
VPg leads to the overcome of the strain-specific resistance to systemic infection and confirms the role of central part of VPg for systemic invasion of the potyviruses [109]. A Tyr63Ala mutation did not prevent replication completely but blocked spreading of the virus [106]. This protein was found to be phosphorylated as a part of the virus particle by the cellular kinase activity, which means that VPg is accessible to protein-protein interactions [110]. Interactions with HCPro were shown in the papers of Yambalo et al. and Roudet-Tavert et al. [111,112].

The potyvirus-interacting protein (PVIP), a plant-specific protein with some homologues has been identified in many plants. PVIP function is still discussed, however, as it probably serves as a control in chromatin remodelling and as an ancillary factor to support potyvirus movement in plants [113]. Co-immunoprecipitation and bimolecular fluorescence complementation (BiFC) assays revealed that P3N-PIPO interacts with host protein PCaP1, a cation-binding protein that attaches to the plasma membrane via myristoylation. PIPO domain of P3N-PIPO binds PCaP1; in this process myristoylation of PCaP1 is unnecessary for interaction with P3N-PIPO. It seems that PCaP1 links a complex of viral proteins and genomic RNA to the plasma membrane by binding P3N-PIPO, enabling localization to the plasmodesmata and cell-to-cell movement [55]. Phosphorylation itself probably plays important role in the VPg-mediated functions during the infection cycle of potyviruses [110]. Interactions between viral RNA polymerase and VPg support the VPg role in a viral RNA synthesis [114]. VPg displays still investigated roles in nuclei of host plants [115,116]. However, the nuclear VPg localization is not the only localization in infected cells. Using green fluorescent protein technologies, VPg was localized in endoplasmic reticulum with the probable role in viral RNA translation [117]. Mutants in the VPg domain demonstrate inhibition of nuclear transport debilitated viral genome amplification. Interactions between VPg and eIF 4E that indicate its role in the initiation of translation of the viral RNA has been demonstrated and represent a critical element for virus production [118122]. VPg is probably an efficient modulator of eIF 4E biochemical function $[123,124]$ and directs eIF 4E to promote viral RNA expression [125]. Interactions of VPg with next molecules, such as the phosphatidylserine of biomembranes [126]. However, the significance of these interactions must be further investigated. The NIb acts as a RNA-dependent RNA polymerase and is generally localized in the nuclei of infected plants [127]. Interactions between NIb and VPg have been demonstrated in some papers [128-131]. NIb role in uridylylation of VPg protein was investigated in potato virus $A$ model and it seems that has important function in the regulation of RNA synthesis [131]. NIb introduction into plants (transgenic plants) may pose one of the directions in progress in the field of potyvirusresistant plants $[132,133]$.

The coat protein (CP) represents the multifunctional protein [134]. It is important for transmission of Potyviridae and, in addition, the degree of the identity between coat protein sequences can be used for the determination of relationship within the Potyviridae [135-143]. The role of CP and its binding with the helper component (HC) in aphid transmission is demonstrated [144-146]. CP-HC interactions are highly specific and require a Cys-Cys-Cys motif for specific interaction with CP Asp-Ala-Gly (DAG) motif [147]. Changes in DAG motif are the cause of systemic infection failure, but they do not affect replication and production of virions [148,149]. Further, N terminus of CP demonstrates next factor in the specificity for HC. This fact was confirmed by the work of Dombrovski et al., who compared the differences between two potyviruses - zucchini yellow mosaic virus (ZYMV) and turnip mosaic virus (TuMV) with the same DAG domain [150]. Amino acid at the position 47 of the CP in 
the pea seed-borne mosaic potyvirus is highly important for ability of potyviruses to induce systemic infection [151]. However, due to the CP N-terminal region hypervariability, individual cases must be considered separately. CP is able to interact with NIb protein. However, the role of this interaction in the functioning of both proteins remains unknown [114]. Different plant viruses have been demonstrated to induce the expression of HSP70. This fact has also been established in some potyviruses, where up-regulation of HSP70 (heat shock protein gene) via a cytoplasmic unfolded protein response was established [152,153]. In addition, CP plays important role in these processes increased amount of aggregated viral CP was observed under tobacco mosaic virus infection. Hafren et al. observed CP-mediated defect associated with replication under HSP70 down-regulation. In addition, authors also propose the role of cochaperone CPIP in these processes [154]. The full-length vanilla necrosis potyvirus (VNV) coat protein (CP) gene was introduced into Nicotiana benthamiana plants via Agrobacterium tumefaciens-mediated transformation in the paper by Wang et al. [155]. Plants containing a full-length sense CP gene were highly resistant to virus infection. Similar papers demonstrating protective effect of CP gene expression in plants were demonstrated later [156,157]. However, the resistance is RNA-mediated. This circumstance is of high importance in biotechnology and engineering the virus-resistant plants [158-162]. However, virus resistance obtained by expressing the regions of a plant viruses genome in transgenic plants may be suppressed by the infection with another virus, which indicates the specificity in virus resistance [163]. On the other hand, the paper by Shand et al. points at the extensive cellular changes including disruption of the normal cell morphology, mitochondrial and chloroplast internal structures reorganization and formation of the atypical lipid deposits [164].

The $6 \mathrm{~K} 2$ protein is as well as $6 \mathrm{~K} 1$ protein only poorly understood. This transmembrane protein has no enzymatic function and enables anchoring the viral replication complex to membranes. It induces the formation of vesicles from endoplasmic reticulum membranes of the host leading to the formation of active replication compartments that contain all components required for virus replication. This fact has been confirmed especially by the papers of Restrepo-Hartwig et al., who investigated a role of 6K2 protein in regulation of transport of the NIa via 6K2-NIa interactions to the nucleus $[115,165,166]$. Deletion or insertion of six histidine residues into various positions of membrane-bound $6 \mathrm{~K} 2$ protein of potato virus $A$ inhibited systemic infection independently in a host-specific manner $[103,167]$. Characterization and function of above-discussed proteins are summarized in Table 2.

\section{Plum pox virus}

The plum pox virus was firstly observed on plums in 1915 in Bulgaria and the disease was described in 1932 by Atanasoff [184]. Therefore, Eastern Europe was the localization of the first PPV epidemic. Later, PPV was reported on apricots (1933, by the same author who described the first PPV observation), on peaches (1961) and on sour cherries in the 1980's [185]. Between 1932 and 1960, the disease caused by PPV moved from Bulgaria into Yugoslavia, Hungary, Romania, Albania, Czechoslovakia, Germany and Russia. Progression of disease in Western Europe was recorded after Word War II from Germany and Austria to The Netherlands, Switzerland, Greece, England and Turkey (1960s), then France, Italy, and Belgium (early 1970s), Spain and Portugal (early 1980s), Egypt, Syria and Cyprus (late 1980s). After 1990s, the disease was recorded in Chile, USA (Adams County, Pennsylvania, in 1999), Jordan, India and Canada. However, new reports about PPV 
occurrence (including individual PPV strains) still appear [186-191]. In Kazakhstan, PPV was firstly detected on plum and apricot trees in 2004 [192]. In 2005, plum pox virus has been found on apricot trees in China (Hunan Province of China, plants with typical yellow rings and diffused chlorotic spots) [193], in 2006, sharka disease in Prunus species was demonstrated in Argentina [194] and Pakistan [195]. One of the latest reports indicates detection of PPV in commercial Japanese apricot trees in Tokyo [196]. For the disease distribution and status, see Table 3.

PPV as a member of Potyviridae, which is a RNA virus with flexuous filamentous particles approximately $750 \times 15 \mathrm{~nm}$. It is widely distributed in Europe, North Africa, Asia and both Americas. As a natural host, PPV is restricted only to members of genus Prunus L. with above-mentioned exception. However, many experimental host plants have been identified. PPV is transmitted by several aphid species (see Table 1) [240]; however, it is also graft-transmissible to susceptible Prunus species and sap-transmissible to a wide range of herbaceous species. Symptoms of "sharka" highly depend on sensitivity of host plant and environmental conditions, especially on the weather conditions and age of the trees [241].

Table 1. Characterization of Potyviridae proteins including their function and subcellular localization.

\begin{tabular}{|c|c|c|c|}
\hline Protein (size) & Function & Cellular localization & Reference(s) \\
\hline P1 $(32-64 K)$ & $\begin{array}{l}\text { serine proteinase with cis-cleavage activity, } \\
\text { P1/HCpro cleavage site. Responsible for } \\
\text { symptomatolology. Usable for investigation } \\
\text { of potyviruses phylogeny and relationship }\end{array}$ & $\begin{array}{l}\text { Crystalline inclusions in } \\
\text { cytoplasm and nuclei. }\end{array}$ & {$[56,61,63,168-170]$} \\
\hline HCpro $(56-58 \mathrm{~K})$ & $\begin{array}{l}\text { cysteine proteinase with cis-cleavage activity, } \\
\text { HCpro/P3 cleavage siter Aphid } \\
\text { transmission, systemic movement, } \\
\text { suppression of gene silencing, symptoms } \\
\text { development. }\end{array}$ & $\begin{array}{l}\text { Cytoplasm, aggregates } \\
\text { along the endoplasmic } \\
\text { reticulum. }\end{array}$ & {$[82,171-175]$} \\
\hline P3 (37 K) & $\begin{array}{l}\text { plant pathogenicity }- \text { virulence, viral } \\
\text { infection cycle. }\end{array}$ & $\begin{array}{l}\text { Crystalline inclusions in } \\
\text { cytoplasm and nuclei. } \\
\text { Endoplasmic reticulum } \\
\text { (punctuate inclusions in } \\
\text { association with Golgi) }\end{array}$ & {$[86,91,92,169,176,177]$} \\
\hline 6K1 (6 K?) & cell-to-cell movement?, role in virulence? & The cell periphery. & {$[94,178,179]$} \\
\hline CI $(70 \mathrm{~K})$ & $\begin{array}{l}\text { RNA helicase required for genome } \\
\text { replication. Cell-to-cell movement. Long- } \\
\text { distance movement. Development of } \\
\text { symptoms. Breaking the host resistance. }\end{array}$ & $\begin{array}{l}\text { Cytoplasm, conical } \\
\text { structures attached to } \\
\text { plasmodesmata. }\end{array}$ & {$[95,97-99,180]$} \\
\hline $6 \mathrm{~K} 2$ & $\begin{array}{l}\text { anchoring the viral replication complex to } \\
\text { membranes. Long-distance movement. } \\
\text { Development of systemic infection. }\end{array}$ & $\begin{array}{l}\text { Crystalline inclusions in } \\
\text { cytoplasm and nuclei. }\end{array}$ & {$[103,167,169]$} \\
\hline VPg & $\begin{array}{l}\text { covalently links the } 5^{\prime} \text { end of the viral RNA } \\
\text { via tyrosine residue. Viral cycle. Systemic } \\
\text { infection. Overcoming the eIF4E-based } \\
\text { recessive resistance. }\end{array}$ & $\begin{array}{l}\text { Endoplasmic reticulum, } \\
\text { nucleus, nucleolus. }\end{array}$ & {$[100,102,104,114,117]$} \\
\hline NIa-Pro & $\begin{array}{l}\text { NIa-pro cysteine proteinase. } \\
\text { Host specificity. Host DNA cleavage activity. }\end{array}$ & $\begin{array}{l}\text { Nuclei of infected cells in } \\
\text { the form of inclusion } \\
\text { bodies. }\end{array}$ & {$[71,75]$} \\
\hline $\mathrm{NIb}$ & $\begin{array}{lcc}\text { RNA-dependent } & \text { RNA } & \text { polymerase. } \\
\text { Genome/viral replication. } & \end{array}$ & $\begin{array}{l}\text { Nuclei of infected cells in } \\
\text { the form of inclusion } \\
\text { bodies. Cytoplasm. }\end{array}$ & {$[116,127,131]$} \\
\hline $\mathrm{CP}$ & $\begin{array}{l}\text { Aphid transmission. Cell-to-cell and long- } \\
\text { distance movement. Virion assembly. }\end{array}$ & $\begin{array}{l}\text { Plasmodesmatal } \\
\text { connections between } \\
\text { infected leaf mesophyll } \\
\text { cells. Cytoplasm of } \\
\text { infected cells. }\end{array}$ & {$[96,144-146,181-183]$} \\
\hline
\end{tabular}


Table 2. Sharka disease status in different countries. * - there are no data since 2003

Disease status

Widespread (high level)

Restricted distribution (heterogeneous levels)

Introduced, established

Introduced, eradicated

Not present

Unknown status

\section{Country}

Croatia, Greece, Bulgaria, Germany, Hungary,

Poland, Romania, Russia, Serbia, Slovakia

Albania, Argentina, Austria, Canada, Cyprus,

Czech Republic, Egypt, France, Italy, Iran,

Kazakhstan, Luxembourg, Moldova, Norway,

Pakistan, Portugal, Southern Russia, Slovenia,

Spain, Syria, Turkey, Ukraine, United Kingdom,

United States

Azores, Bosnia-Herzegovina, Chile, Some states of former USSR including Central Asia, India, Jordan, Lithuania, The Netherlands, Switzerland, Tunisia

Belgium, Denmark

Estonia, Finland, Ireland, Israel, Lebanon, Malta, Morocco, Palestine, Sweden
Reference(s)

[197-210]

$[192,195,197,208,211-229]$

$[197,208,218,230-235]$

$[197,208]$

$[197,208,236,237]$

$[208,238,239]$

PPV usually affects both the leaves (leaf symptoms) and the fruit (fruit symptoms) of the plants. The intensity of fruit symptoms is usually significantly increased by the age of infected plants. The symptoms include chlorotic spots or rings, oak-leave patterns and vein clearing on leaves (plum), chlorotic pale-green rings and lines on leaves (apricot), small chlorotic blotches and distortion of the leaves (peach) or pale green patters and rings (cherry) [242,243]. Shallow rings and arabesque depressions, sometimes with brownish or reddish necrotic flesh (plums), light colored depressed rings (apricot), pale rings with diffuse bands on the epidermis (peach) or chlorotic and necrotic rings (cherry) are the main symptoms in the fruits [242]. In addition, fruits may drop prematurely [241]. Infection is usually symptomless in almond. On the other hand, in vitro explants lack the presence of symptoms typical for PPV infection; only typical interveinal chlorosis produced by PPV is visible [244]. This fact must be discussed in the light of the composition of cultivation medium, which represents complex matrix composed of macro- and microelements, as well as source of carbon (sugar(s)) and plant growth regulators - phytohormones. Just phytohormones play crucial role in the regulation of physiological processes as well as processes directing to the programmed cell death [245]. Most of the observable symptoms are probably dependent on a complex of virus-host interactions, where several or all viral genes could be involved in some way. On the other hand, the work of Clemente-Moreno et al. brings interesting findings and shows the possible protective role of ferrulic acid [244]. The work of Nagyova et al. revealed the role the 3' proximal part of the plum pox virus $P 1$ gene in the virus-host interactions resulting in various pathotypes and demonstrated a different relative importance of particular PPV genes for symptom manifestation in different 
herbaceous host plant species [246]. There was an effort of several working groups to classify PPV in accordance with various characteristics, especially on the symptoms caused in experimental conditions of different plant hosts [27,247]. Based on different experimental plant hosts and symptoms, different strains have been described. Classification based on Chenopodium foetidum Lam. as an experimental plant host ranks PPV isolates to yellow, intermediate and necrotic strains [248]. Classification based on molecular-biological data initially brings the recognition of six strains of plum pox virus, see Table 4. Nevertheless, new isolates still occur and there is an effort for the establishment new PPV strains (for example "PPV-T, PPV-Penn, etc."; however, these are still only isolates, for example PPV-Penn isolate(s) belongs to the PPV-D strain)[249,250]. On the other hand, PPV-EA isolate demonstrates 79$80 \%, 80 \%, 77 \%$, and $77 \%$ homology with isolates of strains $\mathrm{D} / \mathrm{M}, \mathrm{Rec}, \mathrm{C}$, and $\mathrm{W}$, respectively) and is classified as a strain [251,252]. The same situation is in the case of PPV-W that represents a new strain that occurs in Canada and Latvia [253].

Table 3. Classification of PPV strains, their first identification, characterization and distribution. * - isolate, ** - sour cherry isolate with unclear taxonomic relationship, in table as a strain. In addition, isolates are indicated in italics in the table.

\begin{tabular}{|c|c|c|c|c|}
\hline Strain/Isolate* & $\begin{array}{c}\text { First } \\
\text { identification }\end{array}$ & Characterization & Distribution & References \\
\hline $\begin{array}{l}\text { PPV-M } \\
\text { (Marcus) }\end{array}$ & $\begin{array}{l}\text { Peach in northern } \\
\text { Greece }\end{array}$ & $\begin{array}{l}\text { Common strain in southern, } \\
\text { eastern and central Europe. Spread } \\
\text { rapidly by aphids, epidemic strain } \\
\text { of PPV. } \\
\text { Apricot, peach, plum. }\end{array}$ & $\begin{array}{c}\text { Austria, Bosnia and } \\
\text { Herzegovina, Bulgaria, } \\
\text { Croatia, Czech } \\
\text { Republic, France, } \\
\text { Germany, Hungary, } \\
\text { Iran, Italy, Jordan, } \\
\text { Kosovo, Serbia, } \\
\text { Slovakia, Slovenia, } \\
\text { Spain, Romania, Turkey }\end{array}$ & {$[10,14,18,199,250,254-271]$} \\
\hline PPV-D (Dideron) & $\begin{array}{l}\text { Apricot in Southern } \\
\text { France }\end{array}$ & $\begin{array}{l}\text { The most common in western } \\
\text { Europe, epidemic strain of PPV. } \\
\text { Apricot, peach (only poorly), } \\
\text { plum. }\end{array}$ & $\begin{array}{c}\text { Bosnia and } \\
\text { Herzegovina, Bulgaria, } \\
\text { Canada, Chile, Croatia, } \\
\text { Czech Republic, } \\
\text { France, Hungary, Japan, } \\
\text { Kosovo, Lithuania, } \\
\text { Romania, Slovakia, } \\
\text { Spain, Turkey, Ukraine }\end{array}$ & $\begin{array}{l}{[18,19,196,218,254,258,265,268,271} \\
279]\end{array}$ \\
\hline $\begin{array}{l}\text { PPV-rec } \\
\text { (recombinant) }\end{array}$ & $\begin{array}{l}\text { Recombination } \\
\text { between PPV-M and } \\
\text { PPV-D }\end{array}$ & $\begin{array}{l}\text { Widespread in several central and } \\
\text { eastern Europe countries. } \\
\text { Efficiently transmitted by aphids. } \\
\text { Plums. }\end{array}$ & $\begin{array}{c}\text { Bosnia and } \\
\text { Herzegovina, Bulgaria, } \\
\text { Croatia, Czech republic, } \\
\text { Germany, Hungary, } \\
\text { Italy, Kosovo, Serbia, } \\
\text { Slovakia, Slovenia } \\
\end{array}$ & {$[14,265,267,271,277-281]$} \\
\hline $\begin{array}{l}\text { PPV-EA } \\
\text { (El Amar) }\end{array}$ & Apricot from Egypt & $\begin{array}{l}\text { Only Egypt. Limited data about } \\
\text { distribution. } \\
\text { Apricot, peach, plum trees. }\end{array}$ & Egypt & [282-286] \\
\hline $\begin{array}{l}\text { PPV-C** } \\
\text { (Cherry) }\end{array}$ & $\begin{array}{ll}\text { Cherry } & \text { from } \\
\text { Moldova } & \end{array}$ & $\begin{array}{l}\begin{array}{l}\text { Eastern and central } \\
\text { countries, Italy } \\
\text { eradicated). } \\
\text { (probably } \\
\text { Transmitted }\end{array} \\
\text { efficiently by aphids. } \\
\text { Sweet (PPV-SwC) and sour cherry } \\
\text { (PVP-SoC). }\end{array}$ & $\begin{array}{l}\text { Hungary, Italy, } \\
\text { Moldova, Romania }\end{array}$ & [287-290] \\
\hline$P P V-T^{*}$ (Turkey) & $\begin{array}{l}\text { Plum from Ancara } \\
\text { region, Turkey }\end{array}$ & Turkey, data still limited. & Turkey & {$[250]$} \\
\hline $\begin{array}{l}\text { PPV-Penn* } \\
\text { (Pennsylvania) }\end{array}$ & $\begin{array}{l}\text { Three different } \\
\text { growers. Peach, } \\
\text { nectarine, }\end{array}$ & $\begin{array}{l}\text { USA, firstly in Adams County, } \\
\text { Pensylvania in 1999. }\end{array}$ & USA & {$[291,292]$} \\
\hline $\begin{array}{l}\text { PPV-W } \\
\text { (Winona) }\end{array}$ & Plum from Canada & $\begin{array}{l}\text { Canada, found in Latvia (The LV- } \\
141 \mathrm{pl} \text { and LV-145bt isolates } \\
\text { appear to be representatives of the } \\
\text { "ancestral" PPV-W strain) }\end{array}$ & Canada, Latvia & {$[253,293]$} \\
\hline
\end{tabular}




\section{Plum pox virus genome organization}

PPV virions are long, flexuous and rod-shaped, approximately $750 \mathrm{~nm}(660-750 \mathrm{~nm})$ in length and $15 \mathrm{~nm}(12.5-20 \mathrm{~nm})$ in width [294]. PPV as a member of Potyviridae has the structure typical for all potyviruses with exception of Bymovirus. The molecule of ssRNA is of positive polarity. The RNA of PPV has a VPg protein linked to its 5 'end and a long poly(A) tail, which is heterogenous in its size at its 3 'end [295]. In the case of an aphid non-transmissible PPV, excluding a 3 'terminal poly(A) sequence the ssRNA is 9741 nucleotides in length. The 3'noncoding region is 220 nucleotides in length without the poly(A) tail [296]. PPV genome contains a long open reading frame starting at the first AUG codon, nucleotide 36, that is translated upon infection, starting at the second AUG codon as nucleotide 147, into a large polyprotein of $355.5 \mathrm{kDa}[70,295,297]$. There are still unanswered questions about initiation of potyviruses translation via recognition of the specific viral sequences [125,298]. Because potyviruses including PPV have relatively short 5'non-coding regions with a low content of cytosine and guanine, they avoid a stable secondary structures and lack nonfunctional intraleader opening reading frames [299,300]. Cap-independent internal initiation of translation has been proposed for four members of the genus Potyvirus [301,302]. Work of Simón-Buela et al. presents different in vitro and in vivo evidence of cap-independent leaky scanning as the mechanism of translation initiation of PPV genomic RNA [303]. Originated polyprotein precursor is co- and posttranslationally cleaved by three virus-encoded proteinases into 11 mature proteins - P1, HCpro, P3, P3N-PIPO, 6K1, CI, 6K2, NIa (respectively VPg and NIa-Pro), NIb and CP. CP protein of about 36 $\mathrm{kDa}$ forms helically arranged "coat". Similarly to other potyviruses, the PPV P1 proteinase represents together with $\mathrm{P} 3 / 6 \mathrm{~K} 1,6 \mathrm{~K} 2, \mathrm{NIa} / \mathrm{VPg}$ and $\mathrm{N}$-terminal domain of $\mathrm{CP}$ highly variable protein [285,304,305]. This variability enables the determination of PPV isolates and their further characterization [285,304-306]. The untranslated region of PPV consists of 147 nucleotides, starting with four adenine residues. It seems that intact $5^{\prime}$ end is not essential for PPV replication. PPV 5' untranslated region that is essential for virus replication is confined to the first 35 residues. Deletion of a long sequence between nucleotide 39 and 145 did not affect the rate of infection and viral accumulation, but affected process of pathogenesis [307,308].

\section{Plum pox virus transmission and cytological, histological and biochemical changes in infected plants}

The PPV transmission is widely discussed in the two directions as aphid and non-aphid transmission. PPV is transmitted over short-distances in a non-persistent manner by Aphis fabae Scopoli (Aphididae), Aphis gossypii Glover (Aphidae), Aphis spiraecola Patch (Aphididae), Brachycaudus persicae Passerini (Aphididae), Myzus persicae Sulzer (Aphididae) and next members of Aphididae [309-313]. Long-distance transmission is based on non-aphid transmission, this means on the spreading of infected plants and infected plant parts. The grafting may represent important risk in PPV spreading [24,314]. Milusheva et al. indicates the possibility of PPV transmission by infected seeds in a cultivar-dependent manner [315], however, some previously published papers disproves the possibility of PPV transmission by seeds [316,317]. The next fate of PPV and symptoms expression in infected plants is discussed. In stems of infected plants, PPV is localized in xylem and pith, which may 
indicate its possible spreading via xylem part of vascular tissue of infected plants [318]. This xylem transport does not suppose the transport for long distances, but for short distances (cell-to-cell) in the horizontal direction, which may be responsible for the localization of PPV in xylem and pith. This type of transport is provided by parenchyma cells. In addition, these cells are interconnected with other parenchyma cells; strict compartmentation is not possible. Later, this localization has been made more accurate. Hoffmann et al. proved the PPV presence in ray and axial parenchyma of vascular tissue of infected plants [319]. In petioles, PPV was demonstrated in epidermis and parenchyma cells of ground tissue, not in xylem [318]. These findings enable to express hypotheses about PPV spreading in plants [320,321]. On the other hand, there are significant differences between resistant and susceptible cultivars. Whereas the long-distance PPV spreading is highly limited in resistant cultivars, PPV susceptible cultivars allow long-distance PPV transport via xylem and the development of symptoms of sharka disease [320,322]. The differences between cell-to-cell (short-distance) and long-distance PPV transport between individual plant cultivars have been recorded, however, there are still unanswered questions [323]. Plum pox virus infection leads to the changes on different levels, i.e. cell and tissue as well as biochemical $[1,324]$. Whereas the changes in subcellular and cellular levels are connected with subcellular compartmentation of individual PPV proteins [320], changes in biochemistry of infected plants and resistant/susceptible plants may have practical impact in utilization of enzymes/proteins as markers of sharka disease. The paper by Hernandez et al. described the response of differently sensitive apricot (Prunus armeniaca L.) cultivars to plum pox virus infection [325]. This paper is interesting due to choice of cultivars, both resistant (Goldrich) and sensitive (Real Fino), and comparison of responses at antioxidant enzymes levels [325]. The most significant changes were observed in the case of superoxide dismutase(s) (SODs) and ascorbate peroxidase (APX) enzymes. Compared to sensitive cultivar, the significant decrease of APX activity in resistant cultivar was determined. Modifications in peroxidase activity were demonstrated also in Nicotiana clevelandii Gray PPV-infected plants, where the role of gaseous phytohormon ethylene in PPV-induced senescence has been partially revealed [326], and in Chenopodium foetidum Lam. [327]. On the other hand, levels of SODs, glutathione reductase (GR), dihydroascorbate reductase (DHAR) and monodehydroascorbate reductase (MDAR) of resistant cultivar were significantly increased compared to sensitive cultivar. Levels of catalase (CAT) remained unaltered. These results indicate the role of hydrogen peroxide, which is generated by the SOD activity, in response to PPV on the biochemical level. The experimental work continues in the second article of Hernandez et al., in this case focused on the effect of PPV on photosynthesis and again on antioxidant enzymes [328]. These results were confirmed in pea plants (Pisum sativum L.), where PPV infection led to the accumulation of reactive oxygen species in chloroplasts under affecting of photosynthetic processes [329]. This fact is in agreement with papers focused on interactions between potyviral proteins and proteins of photosynthetic apparatus [98].The above-mentioned facts may be a reaction on its damage. In the third study, the same authors investigated response to long-term plum pox virus infection in peach plants (Prunus persica (L.) Batch cv. GF305 with the great susceptibility to PPV) with the focus on oxidative stress [328]. In this study, an oxidative stress and antioxidant mechanisms imbalance in accordance with the progress of PPV infection was determined. This fact has been confirmed by the following study of the authors [330]. Diaz-Vivancos et al. described an oxidative stress as a result of PPV infection in the apoplastic space of only susceptible apricot plants [331,332]. Whereas all above- 
mentioned papers were focused on oxidative stress caused by PPV infection, Escalettes et al. determined differential gene expression ins PPV-infected apricot cultivar (cv. Goldrich) [333]. The $\mathrm{CH} 4$ and $\mathrm{CH} 22$ fragments coding for a putative myosin and kinesin, were over-expressed in cv. Goldrich. Both myosin and kinesin are closely associated with cytokinesis, where they serve as motor proteins in the organization of phragmoplast microtubules. In the PPV-infected cv. Goldrich, the transketolase analogue $\mathrm{CH} 15$ was over-expressed, while it presented a very similarly modified expression in the susceptible genotype. Expression of the ankyrin-like $\mathrm{CH} 27$ was obviously enhanced in PPV-inoculated partially resistant apricot and in the susceptible Prunus genotype. The clear repression of $\mathrm{CH} 29$ transcript encoding a putative class III chitinase in the partially resistant genotype suggests a virus-mediated repression of this gene in the Goldrich cultivar [333]. Arabidopsis thaliana (L.) Heynh. was used as a model plant for investigation of gene expression alteration due PPV infection in the following study [334]. Genes associated with soluble sugar, starch and amino acid, intracellular membrane/membrane-bound organelles, chloroplast, and protein fate were up-regulated, while genes related to development/storage proteins, protein synthesis and translation, and cell wallassociated components were down-regulated. These gene expression changes were closely associated with PPV infection and symptom development [334]. The paper by Wang et al. revealed that genes involved in defense, cellular transport, development, protein synthesis, proteins with binding function in the PPV-infected peach leaf tissue are more active than those in PPV-free leaves [335]. The changes of expression of genes (increase of the following gene transcripts: including beta-1,3-glucanase, cytochrome-P450-like protein, cytochrome P450 monooxygenase, heat-shock protein 70, thioredoxin, alcohol dehydrogenase, catalase, cysteine protease inhibitor, translation factor EF-1 alpha, and pathogenesis-related protein (PRI)) in Pisum sativum L. PPV-infected plants support the ability of PPV to induce common stress responses in susceptible plants [335]. The recent studies focused on the changes in growth characteristics and yield of infected plants [336,337]. Similar results were demonstrated by Garcia-Ibarra et al., who investigated changes in protective mechanisms including antioxidant enzymes in peach infected by apple chlorotic leaf spot virus (ACLSV, Flexiviridae). The results show increases in the APX, dehydroascorbate reductase (DHAR), superoxide dismutase (SOD) and glutathione S-transferase (GST) activities, whereas POX suffered a decrease of about $34 \%$ [338]. Induction of oxidative stress by plant viruses is demonstrated in some works, such as Amari et al. [339], Clarke et al. [340], Farkas et al. [341], Fodor et al. [342], and Kiraly et al. [343]. In the lights of these findings, changes in markers of oxidative stress may be useful in the detection of PPV infection. However, further characterization of infected plants is necessary, because changes in antioxidant mechanisms under plant virus infection are indistinctive.

\section{Detection of PPV}

The detection of PPV undergoes rapid development, from the usage of very simple methods based on host plants to molecular-biological methods and techniques. However, significant limitations for methods used in routine testing of plants for PPV must be carefully considered. These limitations are based especially on irregular distribution and translocation of PPV in plants in accordance with growth characteristics. Biological techniques are based on the infection and especially mechanical inoculation of susceptible plants - hosts, including both herbaceous and woody plants, from more than nine plant 
families (Amaranthaceae incl. Chenopodiaceae, Cannabidaceae, Caryophyllaceae, Compositae (Asteraceae), Brassicaceae (Cruciferae), Fabaceae (Leguminosae), Ranunculaceae, Rosaceae and Solanaceae [27,344,345]. Diagnostically important plant host species and symptoms are summarized in Table 4.

Table 4. Susceptible Plum pox virus (PPV) plant host species used in PPV detection and determination.

\begin{tabular}{|l|l|l|}
\hline Plant host species & Symptoms & References \\
\hline $\begin{array}{l}\text { Chenopodium foetidum Lam. } \\
\text { (Amaranthaceae) }\end{array}$ & $\begin{array}{l}\text { yellow spots, some with necrotic centres or } \\
\text { necrotic spots; not systemic }\end{array}$ & {$[327,346-348]$} \\
\hline Nicandra physalodes (L.) P. Gaertn. (Solanaceae) & black-brown necrotic local lesions & {$[344,345]$} \\
\hline $\begin{array}{l}\text { Prunus domestica } \text { L. cv. Italian Prune and cv. } \\
\text { Pozegaca (Rosaceae) }\end{array}$ & chlorotic rings, bands and spots & {$[242,349,350]$} \\
\hline Prunus japonica Thunb. (Rosaceae) & diffused chlorotic spots & {$[18,351]$} \\
\hline Prunus maritima Marsh. (Rosaceae) & chlorotic spots, vein necrosis & {$[351]$} \\
\hline Prunus persica L. (Batsch) cv. GF305 & vein necrosis, malformation of leaves & {$[352,353]$} \\
\hline Prunus sibirica L. (Rosaceae) & green spots and faint line pattern & {$[351,354]$} \\
\hline Prunus tomentosa Thunb. (Rosaceae) & $\begin{array}{l}\text { epinasty and malformation of young leaves, } \\
\text { chlorotic spots, necrotic spots of older leaves }\end{array}$ & {$[23,355,356]$} \\
\hline Sorbus domestica L. (Rosaceae) & yellow spots, leaf chlorosis & {$[208,357]$} \\
\hline
\end{tabular}

The first, but highly important step in progress of PPV diagnostics was based on the serological assay, respectively on the enzyme-linked immunosorbent assay (ELISA), which takes advantages from antibodies and their subsequent detection. One of the first record about the use of antibodies was published in 1980 [358]. ELISA method underwent progress with some modifications and now, it is one of the most popular and used techniques for PPV detection [359-362]. Whereas the usage of polyclonal antibodies, which recognize multiple epitopes on any one antigen, is controversial due to problems with specificity and consequently with sensitivity (serum contains a mixture of antibodies of different affinity), monoclonal antibodies, which detect only one epitope on the antigen, helped to overcome above-mentioned problems and are still widely used in PPV diagnostics [363-367]. Monoclonal antibodies are usually obtained after immunization of BALB/c mice with purified PPV isolates [367,368]. Despite the fact that commercial kits had been available and used before the introduction of 5B-IVIA monoclonal antibody, universal and specific detection of any PPV isolate was achieved by the use of 5B-IVIA monoclonal antibody [23,369]. Generally, this antibody enabled the production and use of commercially available kits for PPV detection, which enable specific identification of respective PPV strain. Antibodies are produced especially against non-structural PPV proteins as P3 [169], 6K2 [169], CP and CI [181,370,371], but also HCPro [181,372], NIb [169,181,373], and P1 [169]. However, non-structural proteins antibodies have not found the application in the practice and are used only for scientific purposes. As a secondary antibody, peroxidase-labelled, biotin-streptavidin system or fluorescence probe-labelled secondary antibodies are 
used [358]. Double Antibody Sandwich Indirect ELISA (DASI-ELISA) and Triple Antibody Sandwich ELISA (TAS-ELISA) have been recently recommended in PPV detection $[13,23,266,269,360,374]$. They are used especially for the determination of individual PPV strains $[23,365,375,376]$. Antibodies may be useful for the investigation of subcellular compartmentation of PPV mature proteins, or, in addition, may be used for subcellular localization of some members of Potyviridae family [181]. In this case, gold-labelled antibodies are used [169,377]. During the years, improved ELISA-based techniques have been proposed and developed. One of the most recent technique is impedimetric immunosensor, which is based on gold electrodes modified with 1,6hexanedithiol, gold nanoparticles, anti-PPV IgG polyclonal antibody and bovine serum albumin. The proposed technique displays very good detection limit $(10 \mathrm{pg} / \mathrm{ml})$ and is able to differentiate the samples from healthy plants and the samples containing $0.01 \%$ of infected plant extract [378]. The PCR-ELISA, respectively RT-PCR-ELISA, which is based on immunoenzymatic detection of PCR products, represents next possibility of ELISA/PCR modification with significant increase of sensitivity compared to both ELISA and PCR methods [374,379,380].

Hybridization techniques are based on an establishing a non-covalent, sequence-specific interaction between two or more complementary strands of nucleic acids into a single hybrid. The revolutionary were two works of Wetzel et al. published in 1991. Authors described molecular cloning and partially described the nucleotide sequence of the genomic RNA of PPV-EA. In addition, they compared this sequence to the corresponding sequence of previously sequenced PPV strains [381]. Finally, a sensitive, polyvalent assay based on the polymerase chain reaction (PCR) was developed for plum pox potyvirus (PPV) detection. This technique was adapted for a single tube, the chemical denaturation and reverse transcription of the viral RNA followed by the PCR reaction yielding a 243-base-pair product [382]. These two works started the large-scale application of PCR in the practice. Molecular hybridization techniques as well as different PCR-based assays have been developed to detect the PPV RNA presence in the sample [383-386]. PCR is widely used to amplify specific nucleic acid regions; thus, there is a necessity to have primers of known nucleotide sequence. In the past, different primers have been proposed and used, mainly on the HCPro [387], C-terminal part of NIb [265,388], Cterminal part of CP [249,265,389], N-terminal part of CP [390] or 3'-noncoding region [272]. The request to known nucleotide sequence is absolutely necessary also in hybridization techniques, which are popular due to relative simplicity. The paper by Pasquini et al. describes the strategy, development and use of 70-mer oligonucleotide probes specific for determination and genotyping (identification) the individual PPV isolates [391]. Despite the above-mentioned facts, the RNA isolation is the crucial step in these techniques. There are some difficulties connected with PPV RNA isolation from plant tissues, especially higher rate of polyphenolics and polysaccharides, which affect RNA isolation due to formation of complexes with both RNA and proteins. In addition, these compounds are able affect also activity of enzymes (including reverse transcriptase necessary for RNA transcription into cDNA form) used in PCR. One-Step RT-PCR as well as Two-Step RT-PCR is widely used in PPV RNA detection [265,392-396]. Products of PCR may be visualized by the electrophoretic separation of fragments in agarose gel with subsequent labelling by ethidium bromide or SYBR Green [397-399], on the nitrocellulose membrane [400], eventually by immunoenzymatic procedure [379]. There are some techniques, which are based on PCR technique and pose the improvement, especially significant enhancement, of sensitivity. Co-operational PCR (Co-PCR) has been described for sensitive detection 
of plant viruses and bacteria [401-403]. This technique, carried out in a single reaction, minimizes contamination risks and has a level of sensitivity similar to nested PCR and real-time PCR. In addition, it can be coupled with dot blot hybridization, making it possible to characterize the nucleotide sequence [401]. A highly sensitive assay, based on the polymerase chain reaction amplification of cDNA synthesized from the viral RNA of antibody-captured viral particles was developed by Wetzel et al. in 1992 [404]. The immunocapture step, by allowing the use of large sample volumes and by the viral particle pre-purification it achieves, dramatically increased the sensitivity of the assay. Recently, modifications of this technique are widely used. An immunocapture reverse transcription-polymerase chain reaction (IC-RT-PCR) based assay for the detection and identification of plant viruses represents technique using clarified plant extracts with degenerate primers, without necessity of isolation of total nucleic acids. This technique was used for detection and determination of papaya ringspot virus [405,406], zantedeschia mild mosaic virus [407], and sugarcane streak mosaic virus [408]. In addition, this technique was used in identification of PPV isolates [14,199,265-267,269]. A nucleic acid sequence-based amplification method coupled with flow-through hybridization (NASBA-FH) was developed for plum pox virus (PPV) detection with the detection limit 1000 times higher compared to conventional RT-PCR $[409,410]$. Despite the fact that ELISA followed by PCR techniques is the most frequently used technique in the PPV detection, loop-mediated isothermal amplification (LAMP) will probably become the most frequently applied approach in PPV detection. The great advantage of LAMP is its enormous rate of amplification paired with a very high specificity and low artefact susceptibility, which means great specificity [411]. Spot real-time RT-PCR is a method for detection of plum pox virus using conventional ELISA plant crude extracts immobilized on paper. This method has been developed to overcome the need of RNA isolation [412].

The field of nanotechnology is focused on the study and control of phenomena and materials and length scale below $100 \mathrm{~nm}$, it means $1-100 \mathrm{~nm}[413,414]$. This definition is not the only one, which tries to define nanotechnology. One of the most important criterions consists in accentuation the special properties of nanomaterials due to their nanoscaled proportions, which open their unique properties and features [415]. Nanotechnology found its application especially in industry and medicine, especially in electronics, imaging and drug delivery system for targeted therapy [416-426]. On the other hand, their application in the field of plant biology and phytopathology is limited, especially for cell imaging and manipulation [427]. There are works describing nanotechnology application in agriculture in the crop production in improving the yield and product quality [428-432]. On the other hand, plant viruses are considered as used in the nanotechnology, especially due to highly organized protein capsids, which are useful as scaffolds for building nanomaterials [433-435]. Tobacco mosaic virus has found applications as a building block for nanoelectronics as a template for metal deposition, mineralization and the deposition of the silica, such as nanowires and conductive films, as well as in light-harvesting systems [436-440]. Cowpea mosaic virus with its icosahedral protein coat shape can be utilized in non-invasive imaging, biosensors, and in vaccines [434,439,441]. Plant virus nanoparticles may be used in medicine in in vivo targeting and tumor targeting [442,443]. Based on the nanotechnology applications in the field of analytical chemistry [444-448], they represent the principal improvement of serological and immunofluorescence techniques in plant virus isolation and determination. In the field of PPV isolation and identification, there is an important requirement for PPV RNA of the highest quality. Therefore, methods of nanotechnology take advantage of 
nanoparticles on the basis of surface modifications possibility, which can significantly improve the quality of isolated RNA. Magnetic nanoparticles have been used for isolation and purification of nucleic acids; the use of magnetic nanoparticles provides very rapid and simple isolation of nucleic acids [449-456]. In addition, magnetic nanoparticled surface may be variously modified (these modifications include for example the introduction of silanol, epoxide, diol and carboxyl groups respectively). In comparison with traditional methods, the solid-phase process based on the interaction of nucleic acids with chemically-modified surface of magnetic nanoparticles is characterized by convenience, speed, timesaving, and being amenable to automation [457,458]. Using automation together with simple and rapid PPV RNA isolation under high specificity may represent great progress, especially due to the possibility of analyzing many samples in a short time period [459-461]. Generally, in the field of PPV detection, there is only limited number of publications focused on the use of nanoparticles in different isolation/detection steps. A paper by Byzova et al. introduces the possibility of using monoclonal antibodies as gold nanoparticle conjugates (26 nm in diameter) [462]. Using these conjugates with optimal ratio, an express immunochromatographic assay of PPV with a detection limit of $3 \mathrm{ng} / \mathrm{ml}$ and duration of $10 \mathrm{~min}$. was developed [462]. Colloidal gold nanoparticles $(5-60 \mathrm{~nm})$ as a carrier system conjugated with corresponding antibody are used in the paper by Safenkova et al. [463]. This paper demonstrates correlation between gold nanoparticles, respectively conjugate size and affinity. An increase of conjugate size leads to the increase in its affinity [463]. In conclusion, not only improvement of those methods used (ELISA, PCR) and the establishment of new detection techniques, but also the development of new, effective methods usable in PPV RNA isolation with subsequent routine detection, will bring new opportunities to routine PPV detection, and thereby provide the possibility of eradicating plum pox disease as an one of the most devastating viral diseases of stone fruits.

\section{Acknowledgments}

Financial support from the grants NAZV QI 91A032 and CEITEC CZ.1.05/1.1.00/02.0068 is highly acknowledged.

\section{Conflict of Interest}

The authors declare no conflict of interest.

\section{References and Notes}

1. Albrechtova, L. Investigations on the distribution of sharka virus (plum pox virus) in tissue of prunus-domestica. J. Plant Dis. Prot. 1986, 93, 190-201.

2. Neumuller, M.; Hartmann, W. The hypersensitivity of european plum (prunus domestica 1.) against the plum pox virus. In Proceedings of the twentieth international symposium on virus and virus-like diseases of temperate fruit crops - fruit tree diseases, 2008; pp 273-279.

3. Badenes, M.L.; Asins, M.J.; Carbonell, E.A.; Glacer, G. Genetic diversity in apricot, prunus armeniaca, aimed at improving resistance to plum pox virus. Plant Breed. 1996, 115, 133-139. 
4. Balan, V.; Ivascu, A.; Toma, S. Susceptibility of apricot, nectarine and peach cultivars and hybrids to plum-pox virus. In Xvith international symposium on fruit tree virus diseases, 1995; pp 299-305.

5. Martinez-Gomez, P.; Rubio, M.; Dicenta, F.; Gradziel, T.M. Utilization of almond as source of plum pox virus resistance in peach breeding. In Proceedings of the xixth international symposium on virus and virus-like diseases of temperate fruit crops: Fruit tree diseases, 2004; pp 289-293.

6. Pribek, D.; Gaborjanyi, R.; Palkovics, L. Molecular characterization of plum pox virus almond isolate. In Proceedings of the 18th international symposium on virus \& virus-like diseases of temperate fruit crops - top fruit diseases, vols 1 and 2, 2001; pp 91-95.

7. Rubio, M.; Martinez-Gomez, P.; Dicenta, F. Resistance of almond cultivars to plum pox virus (sharka). Plant Breed. 2003, 122, 462-464.

8. Crescenzi, A.; Nuzzaci, M.; Levy, L.; Piazzolla, P.; Hadidi, A. Plum pox virus (ppv) in sweet cherry. In Xvith international symposium on fruit tree virus diseases, 1995; pp 219-225.

9. Fanigliulo, A.; Comes, S.; Crescenzi, A. Evaluation of cherry cultivars for their response to infection by plum pox virus sweet cherry strain. In Proceedings of the xixth international symposium on virus and virus-like diseases of temperate fruit crops: Fruit tree diseases, 2004; pp 309-316.

10. Boeglin, M.; Quiot, J.B.; Labonne, G. Risk assessment of contamination of cherry trees by plum pox virus in france. In Proceedings of the xixth international symposium on virus and virus-like diseases of temperate fruit crops: Fruit tree diseases, 2004; pp 221-224.

11. Damsteegt, V.D.; Scorza, R.; Stone, A.L.; Schneider, W.L.; Webb, K.; Demuth, M.; Gildow, F.E. Prunus host range of plum pox virus (ppv) in the united states by aphid and graft inoculation. Plant Dis. 2007, 91, 18-23.

12. Nemchinov, L.; Hadidi, A. Characterization of the sour cherry strain of plum pox virus. Phytopathology 1996, 86, 575-580.

13. Elibuyuk, I.O. Detection of plum pox virus in ornamental prunus cerasifera. Phytoparasitica 2006, 34, 347-352.

14. Kamenova, I. Prunus cerasifera as a host of plum pox virus in bulgaria. J. Plant Pathol. 2008, 90, $15-18$.

15. Rubio, M.; Garcia-Ibarra, A.; Dicenta, F.; Martinez-Gomez, P. Plum pox virus (sharka) sensitivity in prunus salicina and prunus cerasifera cultivars against a dideron-type isolate. Plant Breed. 2011, 130, 283-286.

16. Kalinina, A.; Brown, D.C.W.; Ravelonandro, M. Susceptibility of ornamental prunus to plum pox potyvirus infection. In Proceedings of the international symposium on biotechnology of temperate fruit crops and tropical species, 2007; pp 601-605.

17. Kegler, H.; Fuchs, E.; Gruntzig, M.; Krczal, G.; Wegener, B. Susceptibility of genotypes of the genus prunus to plum pox potyvirus. J. Plant Dis. Prot. 1996, 103, 255-261.

18. Sebestyen, D.; Nemeth, M.; Hangyal, R.; Krizbai, L.; Ember, I.; Nyerges, K.; Kolber, M.; Kiss, E.; Bese, G. Ornamental prunus species as new natural hosts of plum pox virus and their importance in the spread of the virus in hungary. J. Plant Pathol. 2008, 90, 57-61. 
19. Stobbs, L.W.; Van Driel, L.; Whybourne, K.; Carlson, C.; Tulloch, M.; Van Lier, J. Distribution of plum pox virus in residential sites, commercial nurseries, and native plant species in the niagara region, ontario, canada. Plant Dis. 2005, 89, 822-827.

20. Ilbagi, H.; Citir, A.; Bostan, H. Prunus spinosa 1. - a natural wild host of some important fruit viruses in tekirdag, turkey. In Proceedings of the twentieth international symposium on virus and virus-like diseases of temperate fruit crops - fruit tree diseases, 2008; pp 33-36.

21. Polak, J. The role of prunus spinosa 1 in epidemiology of plum pox virus in the czech republic. In Diagnosis and identification of plant pathogens, 1997; pp 527-530.

22. Polak, J.; Oukropec, I. The determination of sources of resistance to plum pox virus suitable for peach. In Proceedings of the twentieth international symposium on virus and virus-like diseases of temperate fruit crops - fruit tree diseases, 2008; pp 269-272.

23. Cambra, M.; Capote, N.; Olmos, A.; Bertolini, E.; Gorris, M.T.; Africander, N.L.; Levy, L.; Lenardon, S.L.; Clover, G.; Wright, D. Proposal for a new international protocol for detection and identification of plum pox virus: Validation of the techniques. In Proceedings of the twentieth international symposium on virus and virus-like diseases of temperate fruit crops fruit tree diseases, 2008; pp 181-191.

24. Damsteegt, V.D.; Scorza, R.; Gildow, F.E.; Schneider, W.L.; Stone, A.L.; Luster, D.G. Comparative host range of us isolates of plum pox virus among prunus and other woody plant species following graft inoculation or aphid transmission. Phytopathology 2004, 94, S24-S24.

25. Monsion, M.; Briard, P.; Glasa, M.; Ravelonandro, M. Comparative techniques to perform koch's postulates with plum pox virus. In Proceedings of the twentieth international symposium on virus and virus-like diseases of temperate fruit crops - fruit tree diseases, 2008; pp 221-225.

26. Ravelonandro, M.; Briard, P.; Monsion, M. Strategy to identify and to characterize new isolates of plum pox virus. In Proceedings of the xixth international symposium on virus and virus-like diseases of temperate fruit crops: Fruit tree diseases, 2004; pp 171-175.

27. Salvador, B.; Delgadillo, M.O.; Saenz, P.; Garcia, J.A.; Simon-Mateo, C. Identification of plum pox virus pathogenicity determinants in herbaceous and woody hosts. Mol. Plant-Microbe Interact. 2008, 21, 20-29.

28. Baumgartnerova, H. First findings of plum pox virus in walnut trees (juglans regia 1). Acta Virol. 1996, 40, 59-60.

29. Polak, J. Hosts and symptoms of plum pox virus: Woody species other than fruit and ornamental species of prunus. EPPO Bull. 2006, 36, 225-226.

30. Gibbs, A.; Ohshima, K. Potyviruses and the digital revolution. In Annu. Rev. Phytopathol. 2010; Vol. 48, pp 205-223.

31. Gibbs, A.J.; Mackenzie, A.M.; Wei, K.J.; Gibbs, M.J. The potyviruses of australia. Arch. Virol. 2008, 153, 1411-1420.

32. Revers, F.; Le Gall, O.; Candresse, T.; Maule, A.J. New advances in understanding the molecular biology of plant/potyvirus interactions. Mol. Plant-Microbe Interact. 1999, 12, 367 376.

33. Riechmann, J.L.; Lain, S.; Garcia, J.A. Highlights and prospects of potyvirus molecular-biology. Journal of General Virology 1992, 73, 1-16. 
34. Ward, C.W.; Shukla, D.D. Taxonomy of potyviruses - current problems and some solutions. Intervirology 1991, 32, 269-296.

35. Fereres, A.; Kampmeier, G.E.; Irwin, M.E. Aphid attraction and preference for soybean and pepper plants infected with potyviridae. Ann. Entomol. Soc. Am. 1999, 92, 542-548.

36. Manachini, B.; Casati, P.; Cinanni, L.; Bianco, P. Role of myzus persicae (hemiptera : Aphididae) and its secondary hosts in plum pox virus propagation. J. Econ. Entomol. 2007, 100, 1047-1052.

37. Srinivasan, R.; Alvarez, J.M. Effect of mixed viral infections (potato virus y-potato leafroll virus) on biology and preference of vectors myzus persicae and macrosiphum euphorbiae (hemiptera : Aphididae). J. Econ. Entomol. 2007, 100, 646-655.

38. Symmes, E.J.; Perring, T.M. Intraspecific variation in zucchini yellow mosaic virus transmission by myzus persicae and the impact of aphid host plant. J. Econ. Entomol. 2007, 100, 1764-1772.

39. Choi, I.R.; French, R.; Hein, G.L.; Stenger, D.C. Fully biologically active in vitro transcripts of the eriophyid mite-transmitted wheat streak mosaic tritimovirus. Phytopathology 1999, 89, 1182-1185.

40. Stephan, D.; Moeller, I.; Skoracka, A.; Ehrig, F.; Maiss, E. Eriophyid mite transmission and host range of a brome streak mosaic virus isolate derived from a full-length cdna clone. Arch. Virol. 2008, 153, 181-185.

41. Sanchez-Sanchez, H.; Henry, M.; Cardenas-Soriano, E.; Alvizo-Villasana, H.F. Identification of wheat streak mosaic virus and its vector aceria tosichella in mexico. Plant Dis. 2001, 85, 1317.

42. Adkins, S.; Webb, S.E.; Achor, D.; Roberts, P.D.; Baker, C.A. Identification and characterization of a novel whitefly-transmitted member of the family potyviridae isolated from cucurbits in florida. Phytopathology 2007, 97, 145-154.

43. Adkins, S.; Webster, C.G.; Kousik, C.S.; Webb, S.E.; Roberts, P.D.; Stansly, P.A.; Turechek, W.W. Ecology and management of whitefly-transmitted viruses of vegetable crops in florida. Virus Res. 2011, 159, 110-114.

44. Valverde, R.A.; Sim, J.; Lotrakul, P. Whitefly transmission of sweet potato viruses. Virus Res. 2004, 100, 123-128.

45. Dessens, J.T.; Meyer, M. Identification of structural similarities between putative transmission proteins of polymyxa and spongospora transmitted bymoviruses and furoviruses. Virus Genes 1996, 12, 95-99.

46. Chen, J.P. Progress and prospects of studies on polymyxa graminis and its transmitted cereal viruses in china. Progress Nat. Sci. 2005, 15, 481-490.

47. McGrann, G.R.D.; Adams, M.J. Investigating resistance to barley mild mosaic virus. Plant Pathol. 2004, 53, 161-169.

48. Thompson, J.P.; Clewett, T.G.; Jennings, R.E.; Sheedy, J.G.; Owen, K.J.; Persley, D.M. Detection of polymyxa graminis in a barley crop in australia. Austral. Plant Pathol. 2011, 40, 66-75.

49. Campbell, R.N. Fungal transmission of plant viruses. Annu. Rev. Phytopathol. 1996, 34, 87-108. 
50. Kuroda, T.; Nabata, K.; Hori, T.; Ishikawa, K.; Natsuaki, T. Soybean leaf rugose mosaic virus, a new soilborne virus in the family potyviridae, isolated from soybean in japan. Journal of General Plant Pathology 2010, 76, 382-388.

51. Chung, B.Y.W.; Miller, W.A.; Atkins, J.F.; Firth, A.E. An overlapping essential gene in the potyviridae. Proc. Natl. Acad. Sci. U. S. A. 2008, 105, 5897-5902.

52. Wen, R.H.; Hajimorad, M.R. Mutational analysis of the putative pipo of soybean mosaic virus suggests disruption of pipo protein impedes movement. Virology 2010, 400, 1-7.

53. Wen, R.H.; Maroof, M.A.S.; Hajimorad, M.R. Amino acid changes in p3, and not the overlapping pipo-encoded protein, determine virulence of soybean mosaic virus on functionally immune rsv1-genotype soybean. Molecular Plant Pathology 2011, 12, 799-807.

54. Kneller, E.L.P.; Rakotondrafara, A.M.; Miller, W.A. Cap-independent translation of plant viral rnas. Virus Research 2006, 119, 63-75.

55. Vijayapalani, P.; Maeshima, M.; Nagasaki-Takekuchi, N.; Miller, W.A. Interaction of the transframe potyvirus protein $\mathrm{p} 3 \mathrm{n}$-pipo with host protein pcap1 facilitates potyvirus movement. PLoS Pathog. 2012, 8, 1-15.

56. Adams, M.J.; Antoniw, J.F.; Beaudoin, F. Overview and analysis of the polyprotein cleavage sites in the family potyviridae. Mol. Plant Pathol. 2005, 6, 471-487.

57. Verchot, J.; Koonin, E.V.; Carrington, J.C. The 35-kda protein from the n-terminus of the potyviral polyprotein functions as a 3rd virus-encoded proteinase. Virology 1991, 185, 527-535.

58. Yoshida, N.; Shimura, H.; Yamashita, K.; Suzuki, M.; Masuta, C. Variability in the p1 gene helps to refine phylogenetic relationships among leek yellow stripe virus isolates from garlic. Arch. Virol. 2012, 157, 147-153.

59. Salvador, B.; Saenz, P.; Yanguez, E.; Quiot, J.B.; Quiot, L.; Delgadillo, M.O.; Garcia, J.A.; Simon-Mateo, C. Host-specific effect of p1 exchange between two potyviruses. Mol. Plant Pathol. 2008, 9, 147-155.

60. Shi, Y.; Chen, J.; Hong, X.; Adams, M.J. A potyvirus p1 protein interacts with the rieske fe/s protein of its host. Mol. Plant Pathol. 2007, 8, 785-790.

61. Valli, A.; Lopez-Moya, J.J.; Garcia, J.A. Recombination and gene duplication in the evolutionary diversification of $\mathrm{p} 1$ proteins in the family potyviridae. J. Gen. Virol. 2007, 88, 1016-1028.

62. Young, B.A.; Stenger, D.C.; Qu, F.; Morris, T.J.; Tatineni, S.; French, R. Tritimovirus p1 functions as a suppressor of rna silencing and an enhancer of disease symptoms. Virus Res. 2012, 163, 672-677.

63. Rohozkova, J.; Navratil, M. P1 peptidase - a mysterious protein of family potyviridae. J. Biosci. 2011, 36, 189-200.

64. Stenger, D.C.; Hein, G.L.; Gildow, F.E.; Horken, K.M.; French, R. Plant virus hc-pro is a determinant of eriophyid mite transmission. J. Virol. 2005, 79, 9054-9061.

65. Endres, M.; Mlotshwa, S.; Schauer, S.; Bowman, L.; Vance, V. Hc-pro suppression of rna silencing: Towards a mechanism. Phytopathology 2005, 95, S123-S123.

66. Torres-Barcelo, C.; Daros, J.A.; Elena, S.F. Compensatory molecular evolution of hc-pro, an rna-silencing suppressor from a plant rna virus. Mol. Biol. Evol. 2010, 27, 543-551. 
67. Shen, W.T.; Yan, P.; Gao, L.; Pan, X.Y.; Wu, J.Y.; Zhou, P. Helper component-proteinase (hcpro) protein of papaya ringspot virus interacts with papaya calreticulin. Mol. Plant Pathol. 2010, $11,335-346$.

68. Guo, B.H.; Lin, J.Z.; Ye, K.Q. Structure of the autocatalytic cysteine protease domain of potyvirus helper-component proteinase. J. Biol. Chem. 2011, 286, 21937-21943.

69. Matthews, D.A.; Smith, W.W.; Ferre, R.A.; Condon, B.; Budahazi, G.; Sisson, W.; Villafranca, J.E.; Janson, C.A.; McElroy, H.E.; Gribskov, C.L. et al. Structure of human rhinovirus 3c protease reveals a trypsin-like polypeptide fold, rna-binding site, and means for cleaving precursor polyprotein. Cell 1994, 77, 761-771.

70. Riechmann, J.L.; Cervera, M.T.; Garcia, J.A. Processing of the plum pox virus polyprotein at the p3-6k(1) junction is not required for virus viability. J. Gen. Virol. 1995, 76, 951-956.

71. Anindya, R.; Savithri, H.S. Potyviral nia proteinase, a proteinase with novel deoxyribonuclease activity. J. Biol. Chem. 2004, 279, 32159-32169.

72. Han, H.E.; Sellamuthu, S.; Shin, B.H.; Lee, Y.J.; Song, S.; Seo, J.S.; Baek, I.S.; Bae, J.; Kim, H.; Yoo, Y.J. et al. The nuclear inclusion a (nia) protease of turnip mosaic virus (tumv) cleaves amyloid-beta. Plos One 2010, 5.

73. Han, J.S.; Kang, H.J.; Song, B.D.; Choi, K.Y. Novel mechanism of activity control of potyvirus nia protease. Faseb J. 2002, 16, A905-A905.

74. Puhl, A.C.; Giacomini, C.; Irazoqui, G.; Batista-Viera, F.; Villarino, A.; Terenzi, H. Covalent immobilization of tobacco-etch-virus nia protease: A useful tool for cleavage: Of the histidine tag of recombinant proteins. Biotechnol. Appl. Biochem. 2009, 53, 165-174.

75. Chen, K.C.; Chiang, C.H.; Raja, J.A.J.; Liu, F.L.; Tai, C.H.; Yeh, S.D. A single amino acid of niapro of papaya ringspot virus determines host specificity for infection of papaya. Mol. PlantMicrobe Interact. 2008, 21, 1046-1057.

76. Mathur, C.; Jimsheena, V.K.; Banerjee, S.; Makinen, K.; Gowda, L.R.; Savithri, H.S. Functional regulation of pvbv nuclear inclusion protein-a protease activity upon interaction with viral protein genome-linked and phosphorylation. Virology 2012, 422, 254-264.

77. Restrepo, M.A.; Freed, D.D.; Carrington, J.C. Nuclear transport of plant potyviral proteins. Plant Cell 1990, 2, 987-998.

78. Knuhtsen, H.; Hiebert, E.; Purciful.De, Partial-purification and some properties of tobacco etch virus-induced intranuclear inclusions. Virology 1974, 61, 200-209.

79. Shepard, J.F. Electron microscopy of subtilisin-treated tobacco etch virus nuclear and cytoplasmic inclusions. Virology 1968, 36, 20-\&.

80. Sheffield, F.M.L. The cytoplasmic and nuclear inclusions associated with severe etch virus. $J$. Royal Microscop. Soc. 1941, 61, 30-45.

81. Fellers, J.P.; Collins, G.B.; Hunt, A.G. The nia-proteinase of different plant potyviruses provides specific resistance to viral infection. Crop Sci. 1998, 38, 1309-1319.

82. Fukuzawa, N.; Itchoda, N.; Ishihara, T.; Goto, K.; Masuta, C.; Matsumura, T. Hc-pro, a potyvirus rna silencing suppressor, cancels cycling of cucumber mosaic virus in nicotiana benthamiana plants. Virus Genes 2010, 40, 440-446. 
83. Giner, A.; Lopez-Moya, J.J.; Lakatos, L. Rna silencing in plants and the role of viral suppressors. In Rna interference and viruses: Current innovations and future trends, CAISTER ACADEMIC PRESS: WYMONDHAM, 2010; pp 25-46.

84. Reyes, C.A.; De Francesco, A.; Pena, E.J.; Costa, N.; Plata, M.I.; Sendin, L.; Castagnaro, A.P.; Garcia, M.L. Resistance to citrus psorosis virus in transgenic sweet orange plants is triggered by coat protein-rna silencing. J. Biotechnol. 2011, 151, 151-158.

85. Jenner, C.E.; Wang, X.W.; Tomimura, K.; Ohshima, K.; Ponz, F.; Walsh, J.A. The dual role of the potyvirus $\mathrm{p} 3$ protein of turnip mosaic virus as a symptom and avirulence determinant in brassicas. Mol. Plant-Microbe Interact. 2003, 16, 777-784.

86. Lin, L.; Luo, Z.P.; Yan, F.; Lu, Y.W.; Zheng, H.Y.; Chen, J.P. Interaction between potyvirus p3 and ribulose-1,5-bisphosphate carboxylase/oxygenase (rubisco) of host plants. Virus Genes 2011, 43, 90-92.

87. Chowda-Reddy, R.V.; Sun, H.Y.; Chen, H.Y.; Poysa, V.; Ling, H.; Gijzen, M.; Wang, A.M. Mutations in the $\mathrm{p} 3$ protein of soybean mosaic virus g2 isolates determine virulence on rsv4genotype soybean. Mol. Plant-Microbe Interact. 2011, 24, 37-43.

88. Ryslava, H.; Doubnerova, V.; Janoskova, M.; Subr, Z.; Novakova, S.; Cerovska, N. Influence of viral infection on transgenic plants containing genes for nonstructural potyviral proteins hc-pro and p3. Febs J. 2005, 272, 464-464.

89. Saenz, P.; Cervera, M.T.; Dallot, S.; Quiot, L.; Quiot, J.B.; Riechmann, J.L.; Garcia, J.A. Identification of a pathogenicity determinant of plum pox virus in the sequence encoding the cterminal region of protein p3+6k(1). J. Gen. Virol. 2000, 81, 557-566.

90. Suehiro, N.; Natsuaki, T.; Watanabe, T.; Okuda, S. An important determinant of the ability of turnip mosaic virus to infect brassica spp. And/or raphanus sativus is in its p3 protein. J. Gen. Virol. 2004, 85, 2087-2098.

91. Wen, R.H.; Maroof, M.A.S.; Hajimorad, M.R. Amino acid changes in p3, and not the overlapping pipo-encoded protein, determine virulence of soybean mosaic virus on functionally immune rsv1-genotype soybean. Mol. Plant Pathol. 2011, 12, 799-807.

92. Cui, X.Y.; Wei, T.Y.; Chowda-Reddy, R.V.; Sun, G.Y.; Wang, A.M. The tobacco etch virus p3 protein forms mobile inclusions via the early secretory pathway and traffics along actin microfilaments. Virology 2010, 397, 56-63.

93. Eiamtanasate, S.; Juricek, M.; Yap, Y.K. C-terminal hydrophobic region leads prsv p3 protein to endoplasmic reticulum. Virus Genes 2007, 35, 611-617.

94. Hong, X.Y.; Chen, J.; Shi, Y.H.; Chen, J.P. The '6k1' protein of a strain of soybean mosaic virus localizes to the cell periphery. Arch. Virol. 2007, 152, 1547-1551.

95. Carrington, J.C.; Jensen, P.E.; Schaad, M.C. Genetic evidence for an essential role for potyvirus ci protein in cell-to-cell movement. Plant J. 1998, 14, 393-400.

96. RodriguezCerezo, E.; Findlay, K.; Shaw, J.G.; Lomonossoff, G.P.; Qiu, S.G.; Linstead, P.; Shanks, M.; Risco, C. The coat and cylindrical inclusion proteins of a potyvirus are associated with connections between plant cells. Virology 1997, 236, 296-306.

97. Roberts, I.M.; Wang, D.; Findlay, K.; Maule, A.J. Ultrastructural and temporal observations of the potyvirus cylindrical inclusions (cis) show that the ci protein acts transiently in aiding virus movement. Virology 1998, 245, 173-181. 
98. Jimenez, I.; Lopez, L.; Alamillo, J.M.; Valli, A.; Garcia, J.A. Identification of a plum pox virus ci-interacting protein from chloroplast that has a negative effect in virus infection. Mol. PlantMicrobe Interact. 2006, 19, 350-358.

99. Abdul-Razzak, A.; Guiraud, T.; Peypelut, M.; Walter, J.; Houvenaghel, M.C.; Candresse, T.; Le Gall, O.; German-Retana, S. Involvement of the cylindrical inclusion (ci) protein in the overcoming of an eif4e-mediated resistance against lettuce mosaic potyvirus. Mol. Plant Pathol. 2009, 10, 109-113.

100. Tavert-Roudet, G.; Abdul-Razzak, A.; Doublet, B.; Walter, J.; Delaunay, T.; German-Retana, S.; Michon, T.; Le Gall, O.; Candresse, T. The c terminus of lettuce mosaic potyvirus cylindrical inclusion helicase interacts with the viral vpg and with lettuce translation eukaryotic initiation factor 4e. J. Gen. Virol. 2012, 93, 184-193.

101. Ayme, V.; Souche, S.; Caranta, C.; Jacquemond, M.; Chadoeuf, J.; Palloix, A.; Moury, B. Different mutations in the genome-linked protein vpg of potato virus y confer virulence on the pvr2(3) resistance in pepper. Mol. Plant-Microbe Interact. 2006, 19, 557-563.

102. Charron, C.; Nicolai, M.; Gallois, J.L.; Robaglia, C.; Moury, B.T.; Palloix, A.; Caranta, C. Natural variation and functional analyses provide evidence for co-evolution between plant eif4e and potyviral vpg. Plant J. 2008, 54, 56-68.

103. Rajamaki, M.L.; Valkonen, J.P.T. The $6 \mathrm{k} 2$ protein and the vpg of potato virus a are determinants of systemic infection in nicandra physaloides. Mol. Plant-Microbe Interact. 1999, 12, 1074 1081.

104. Valkonen, J.P.T.; Rajamaki, M.L.; Hamalainen, J.; Kekarainen, T.; Oruetxebarria, I. Incompatible potyvirus-host interactions in resistant plants: The viral genome-linked protein (vpg) of potato virus a as an avirulence determinant. In Proceedings of the 7th aschersleben symposium new aspects of resistance research on culitivated plants: Virus diseases, BUNDESANSTALT FUR ZUCHTUNGS FORSCHUNG KULTURPFLANZEN: QUEDLINBURG, 2000; pp 92-95.

105. Puurand, U.; Makinen, K.; Paulin, L.; Saarma, M. The nucleotide-sequence of potato-virus-a genomic rna and its sequence similarities with other potyviruses. J. Gen. Virol. 1994, 75, 457461.

106. Rantalainen, K.I.; Eskelin, K.; Tompa, P.; Makinen, K. Structural flexibility allows the functional diversity of potyvirus genome-linked protein vpg. J. Virol. 2011, 85, 2449-2457.

107. Rajamaki, M.L.; Valkonen, J.P.T. Localization of a potyvirus and the viral genome-linked protein in wild potato leaves at an early stage of systemic infection. Mol. Plant-Microbe Interact. 2003, 16, 25-34.

108. Vuorinen, A.L.; Kelloniemi, J.; Valkonen, J.P.T. Why do viruses need phloem for systemic invasion of plants? Plant Sci. 2011, 181, 355-363.

109. Rajamaki, M.L.; Valkonen, J.P.T. Viral genome-linked protein (vpg) controls accumulation and phloem-loading of a potyvirus in inoculated potato leaves. Mol. Plant-Microbe Interact. 2002, 15, 138-149.

110. Puustinen, P.; Rajamaki, M.L.; Ivanov, K.I.; Valkonen, J.P.T.; Makinen, K. Detection of the potyviral genome-linked protein vpg in virions and its phosphorylation by host kinases. J. Virol. 2002, 76, 12703-12711. 
111. Roudet-Tavert, G.; Michon, T.; Walter, J.; Delaunay, T.; Redondo, E.; Le Gall, O. Central domain of a potyvirus vpg is involved in the interaction with the host translation initiation factor eif4e and the viral protein hepro. J. Gen. Virol. 2007, 88, 1029-1033.

112. Yambao, M.L.M.; Masuta, C.; Nakahara, K.; Uyeda, I. The central and c-terminal domains of vpg of clover yellow vein virus are important for vpg-hcpro and vpg-vpg interactions. J. Gen. Virol. 2003, 84, 2861-2869.

113. Dunoyer, P.; Thomas, C.; Harrison, S.; Revers, F.; Maule, A. A cysteine-rich plant protein potentiates potyvirus movement through an interaction with the virus genome-linked protein vpg. J. Virol. 2004, 78, 2301-2309.

114. Hong, Y.L.; Levay, K.; Murphy, J.F.; Klein, P.G.; Shaw, J.G.; Hunt, A.G. A potyvirus polymerase interacts with the viral coat protein and vpg in yeast-cells. Virology 1995, 214, 159166.

115. Carrington, J.C.; Haldeman, R.; Dolja, V.V.; Restrepohartwig, M.A. Internal cleavage and transproteolytic activities of the vpg-proteinase (nia) of tobacco etch potyvirus in-vivo. J. Virol. 1993, 67, 6995-7000.

116. Hajimorad, M.R.; Ding, X.S.; Flasinski, S.; Mahajan, S.; Graff, E.; HaldemanCahill, R.; Carrington, J.C.; Cassidy, B.G. Nla and nlb of peanut stripe potyvirus are present in the nucleus of infected cells, but do not form inclusions. Virology 1996, 224, 368-379.

117. Beauchemin, C.; Boutet, N.; Laliberte, J.F. Visualization of the interaction between the precursors of vpg, the viral protein linked to the genome of turnip mosaic virus, and the translation eukaryotic initiation factor iso 4e in planta. J. Virol. 2007, 81, 775-782.

118. Borgstrom, B.; Johansen, I.E. Mutations in pea seedborne mosaic virus genome-linked protein vpg alter pathotype-specific virulence in pisum sativum. Mol. Plant-Microbe Interact. 2001, 14, 707-714.

119. Daughenbaugh, K.F.; Fraser, C.S.; Hershey, J.W.B.; Hardy, M.E. The genome-linked protein vpg of the norwalk virus binds eif3, suggesting its role in translation initiation complex recruitment. Embo J. 2003, 22, 2852-2859.

120. Leonard, S.; Plante, D.; Wittmann, S.; Daigneault, N.; Fortin, M.G.; Laliberte, J.F. Complex formation between potyvirus vpg and translation eukaryotic initiation factor $4 \mathrm{e}$ correlates with virus infectivity. J. Virol. 2000, 74, 7730-7737.

121. Leonard, S.; Viel, C.; Beauchemin, C.; Daigneault, N.; Fortin, M.G.; Laliberte, J.F. Interaction of vpg-pro of turnip mosaic virus with the translation initiation factor $4 \mathrm{e}$ and the poly(a)-binding protein in planta. J. Gen. Virol. 2004, 85, 1055-1063.

122. Plante, D.; Viel, C.; Leonard, S.; Tampo, H.; Laliberte, J.F.; Fortin, M.G. Tumip mosaic virus vpg does not disrupt the translation initiation complex but interferes with cap binding. Physiol. Mol. Plant Pathol. 2004, 64, 219-226.

123. Grzela, R.; Strokovska, L.; Andrieu, J.P.; Dublet, B.; Zagorski, W.; Chroboczek, J. Potyvirus terminal protein vpg, effector of host eukaryotic initiation factor eif4e. Biochimie 2006, 88, 887896.

124. Michon, T.; Estevez, Y.; Walter, J.; German-Retana, S.; Le Gall, O. The potyviral virus genome-linked protein vpg forms a ternary complex with the eukaryotic initiation factors eif4e and eif4g and reduces eif4e affinity for a mrna cap analogue. Febs $J$. 2006, 273, 1312-1322. 
125. Eskelin, K.; Hafren, A.; Rantalainen, K.I.; Makinen, K. Potyviral vpg enhances viral rna translation and inhibits reporter mrna translation in planta. J. Virol. 2011, 85, 9210-9221.

126. Rantalainen, K.I.; Christensen, P.A.; Hafren, A.; Otzen, D.E.; Kalkkinen, N.; Makinen, K. Interaction of a potyviral vpg with anionic phospholipid vesicles. Virology 2009, 395, 114-120.

127. Li, X.H.; Valdez, P.; Olvera, R.E.; Carrington, J.C. Functions of the tobacco etch virus rna polymerase (nib): Subcellular transport and protein-protein interaction with vpg/proteinase (nia). J. Virol. 1997, 71, 1598-1607.

128. Daros, J.A.; Schaad, M.C.; Carrington, J.C. Functional analysis of the interaction between vpgproteinase (nia) and rna polymerase (nib) of tobacco etch potyvirus, using conditional and suppressor mutants. J. Virol. 1999, 73, 8732-8740.

129. Guo, D.Y.; Rajamaki, M.L.; Saarma, M.; Valkonen, J.P.T. Towards a protein interaction map of potyviruses: Protein interaction matrixes of two potyviruses based on the yeast two-hybrid system. J. Gen. Virol. 2001, 82, 935-939.

130. Lin, L.; Shi, Y.H.; Luo, Z.P.; Lu, Y.W.; Zheng, H.Y.; Yan, F.; Chen, J.; Chen, J.P.; Adams, M.J.; $\mathrm{Wu}$, Y.F. Protein-protein interactions in two potyviruses using the yeast two-hybrid system. Virus Res. 2009, 142, 36-40.

131. Puustinen, P.; Makinen, K. Uridylylation of the potyvirus vpg by viral replicase nib correlates with the nucleotide binding capacity of vpg. J. Biol. Chem. 2004, 279, 38103-38110.

132. Jones, A.L.; Johansen, I.E.; Bean, S.J.; Bach, I.; Maule, A.J. Specificity of resistance to pea seed-borne mosaic potyvirus in transgenic peas expressing the viral replicase (nib) gene. J. Gen. Virol. 1998, 79, 3129-3137.

133. Sivamani, E.; Brey, C.W.; Dyer, W.E.; Talbert, L.E.; Qu, R.D. Resistance to wheat streak mosaic virus in transgenic wheat expressing the viral replicase (nib) gene. Mol. Breed. 2000, 6, 469-477.

134. Cassidy, B.G.; Nelson, R.S. Differences in protection phenotypes in tobacco plants expressing coat protein genes from peanut stripe potyvirus with or without an engineered atg. Mol. PlantMicrobe Interact. 1995, 8, 357-365.

135. Crescenzi, A.; d'Aquino, L.; Nuzzaci, M.; Ostuni, A.; Bavoso, A.; Comes, S.; De Stradis, A.; Piazzolla, P. Production of strain specific antibodies against a synthetic polypeptide corresponding to the n-terminal region of the plum pox potyvirus coat protein. J. Virol. Methods 1997, 69, 181-189.

136. Gotz, R.; Huth, W.; Maiss, E. Molecular analyses of the coat protein region of different viruses on poaceae belonging to the potyviridae. Agronomie 1995, 15, 491-494.

137. Handley, J.A.; Smith, G.R.; Dale, J.L.; Harding, R.M. Sequence diversity in the coat protein coding region of twelve sugarcane mosaic potyvirus isolates from australia, USA and south africa. Arch. Virol. 1998, 143, 1145-1153.

138. Kobayashi, K.; Rabinowicz, P.; BravoAlmonacid, F.; Helguera, M.; Conci, V.; Lot, H.; Mentaberry, A. Coat protein gene sequences of garlic and onion isolates of the onion yellow dwarf potyvirus (oydv). Arch. Virol. 1996, 141, 2277-2287.

139. Ryu, K.H.; Kim, S.J.; Park, W.M. Nucleotide sequence analysis of the coat protein genes of two korean isolates of sweet potato feathery mottle potyvirus. Arch. Virol. 1998, 143, 557-562. 
140. Valkonen, J.P.T.; Puurand, U.; Slack, S.A.; Makinen, K.; Saarma, M. 3 strain groups of potatoa-potyvirus based on hypersensitive responses in potato, serological properties, and coat protein sequences. Plant Dis. 1995, 79, 748-753.

141. Massey, B.; Cui, X.; Hiebert, E.; Elliott, M.S.; Waipara, N.; Hayes, L.; Charudattan, R. Partial sequencing of the genomic rna of araujia mosaic virus and comparison of the coat protein sequence with those of other potyviruses. Arch. Virol. 2007, 152, 2125-2129.

142. Pfosser, M.F.; Baumann, H. Phylogeny and geographical differentiation of zucchini yellow mosaic virus isolates (potyviridae) based on molecular analysis of the coat protein and part of the cytoplasmic inclusion protein genes. Arch. Virol. 2002, 147, 1599-1609.

143. Sanchez, F.; Wang, X.; Jenner, C.E.; Walsh, J.A.; Ponz, F. Strains of turnip mosaic potyvirus as defined by the molecular analysis of the coat protein gene of the virus. Virus Res. 2003, 94, 3343.

144. Andrejeva, J.; Puurand, U.; Merits, A.; Rabenstein, F.; Jarvekulg, L.; Valkonen, J.P.T. Potyvirus helper component-proteinase and coat protein (cp) have coordinated functions in virus-host interactions and the same cp motif affects virus transmission and accumulation. J. Gen. Virol. 1999, 80, 1133-1139.

145. Atreya, P.L.; Lopezmoya, J.J.; Chu, M.H.; Atreya, C.D.; Pirone, T.P. Mutational analysis of the coat protein n-terminal amino-acids involved in potyvirus transmission by aphids. J. Gen. Virol. 1995, 76, 265-270.

146. Blanc, S.; LopezMoya, J.J.; Wang, R.Y.; GarciaLampasona, S.; Thornbury, D.W.; Pirone, T.P. A specific interaction between coat protein and helper component correlates with aphid transmission of a potyvirus. Virology 1997, 231, 141-147.

147. Flasinski, S.; Cassidy, B.G. Potyvirus aphid transmission requires helper component and homologous coat protein for maximal efficiency. Arch. Virol. 1998, 143, 2159-2172.

148. Lopez-Moya, J.J.; Pirone, T.P. Charge changes near the $\mathrm{n}$ terminus of the coat protein of two potyviruses affect virus movement. J. Gen. Virol. 1998, 79, 161-165.

149. Lopez-Moya, J.J.; Wang, R.Y.; Pirone, T.P. Context of the coat protein dag motif affects potyvirus transmissibility by aphids. J. Gen. Virol. 1999, 80, 3281-3288.

150. Dombrovsky, A.; Huet, H.; Chejanovsky, N.; Raccah, B. Aphid transmission of a potyvirus depends on suitability of the helper component and the $\mathrm{n}$ terminus of the coat protein. Arch. Virol. 2005, 150, 287-298.

151. Andersen, K.; Johansen, I.E. A single conserved amino acid in the coat protein gene of pea seedborne mosaic potyvirus modulates the ability of the virus to move systemically in chenopodium quinoa. Virology 1998, 241, 304-311.

152. Aparicio, F.; Thomas, C.L.; Lederer, C.; Niu, Y.; Wang, D.W.; Maule, A.J. Virus induction of heat shock protein 70 reflects a general response to protein accumulation in the plant cytosol. Plant Physiol. 2005, 138, 529-536.

153. Sugio, A.; Dreos, R.; Aparicio, F.; Maule, A.J. The cytosolic protein response as a subcomponent of the wider heat shock response in arabidopsis. Plant Cell 2009, 21, 642-654.

154. Hafren, A.; Hofius, D.; Ronnholm, G.; Sonnewald, U.; Makinen, K. Hsp70 and its cochaperone cpip promote potyvirus infection in nicotiana benthamiana by regulating viral coat protein functions. Plant Cell 2010, 22, 523-535. 
155. Wang, Y.Y.; Gardner, R.C.; Pearson, M.N. Resistance to vanilla necrosis potyvirus in transgenic nicotiana benthamiana plants containing the virus coat protein gene. J. Phytopathol. 1997, 145, $7-15$.

156. Dinant, S.; Maisonneuve, B.; Albouy, J.; Chupeau, Y.; Chupeau, M.C.; Bellec, Y.; Gaudefroy, F.; Kusiak, C.; Souche, S.; Robaglia, C. et al. Coat protein gene-mediated protection in lactuca sativa against lettuce mosaic potyvirus strains. Mol. Breed. 1997, 3, 75-86.

157. Xu, D.; Liu, H.; Li, F.; Howell, B.; Tian, T.; Li, R. Biological characterization and complete genomic sequence of carrot thin leaf virus. Phytopathology 2011, 101, S195-S195.

158. Fuchs, M.; Gal-On, A.; Raccah, B.; Gonsalves, D. Epidemiology of an aphid nontransmissible potyvirus in fields of nontransgenic and coat protein transgenic squash. Transgenic Res. 1999, 8 , 429-439.

159. Higgins, C.M.; Hall, R.M.; Mitter, N.; Cruickshank, A.; Dietzgen, R.G. Peanut stripe potyvirus resistance in peanut (arachis hypogaea 1.) plants carrying viral coat protein gene sequences. Transgenic Res. 2004, 13, 59-67.

160. Ravelonandro, M.; Dunez, J.; Scorza, R.; Labonne, G. Challenging transgenic plums expressing potyvirus coat protein genes with viruliferous aphids. In 17th international symposium on virus and virus-like diseases of temperate fruit crops: Fruit tree diseases, vols 1 and 2, INTERNATIONAL SOCIETY HORTICULTURAL SCIENCE: LEUVEN 1, 1998; pp 413-420.

161. Scorza, R.; Callahan, A.M.; Levy, L.; Damsteegt, V.; Ravelonandro, M. Transferring potyvirus coat protein genes through hybridization of transgenic plants to produce plum pox virus resistant plums (prunus domestica 1.). In 17th international symposium on virus and virus-like diseases of temperate fruit crops: Fruit tree diseases, vols 1 and 2, INTERNATIONAL SOCIETY HORTICULTURAL SCIENCE: LEUVEN 1, 1998; pp 421-427.

162. Yadav, N.; Khan, J.A. Over expression of narcissus potyvirus coat protein in e. Coli. Indian J. Virol. 2009, 20, 44-44.

163. Savenkov, E.I.; Valkonen, J.P.T. Coat protein gene-mediated resistance to potato virus a in transgenic plants is suppressed following infection with another potyvirus. J. Gen. Virol. 2001, $82,2275-2278$.

164. Shand, K.; Theodoropoulos, C.; Stenzel, D.; Dale, J.L.; Harrison, M.D. Expression of potato virus y cytoplasmic inclusion protein in tobacco results in disorganization of parenchyma cells, distortion of epidermal cells, and induces mitochondrial and chloroplast abnormalities, formation of membrane whorls and atypical lipid accumulation. Micron 2009, 40, 730-736.

165. Restrepohartwig, M.A.; Carrington, J.C. Regulation of nuclear transport of a plant potyvirus protein by autoproteolysis. J. Virol. 1992, 66, 5662-5666.

166. Restrepohartwig, M.A.; Carrington, J.C. The tobacco etch potyvirus 6-kilodalton protein is membrane-associated and involved in viral replication. J. Virol. 1994, 68, 2388-2397.

167. Spetz, C.; Valkonen, J.P.T. Potyviral 6k2 protein long-distance movement and symptominduction functions are independent and host-specific. Mol. Plant-Microbe Interact. 2004, 17, 502-510.

168. Yoshida, N.; Shimura, H.; Yamashita, K.; Suzuki, M.; Masuta, C. Variability in the p1 gene helps to refine phylogenetic relationships among leek yellow stripe virus isolates from garlic. Arch. Virol. 2011, 157, 147-153. 
169. Martin, M.T.; Gelie, B. Non-structural plum pox potyvirus proteins detected by immunogold labelling. Eur. J. Plant Pathol. 1997, 103, 427-431.

170. Arbatova, J.; Lehto, K.; Pehu, E.; Pehu, T. Localization of the $\mathrm{p} 1$ protein of potato y potyvirus in association with cytoplasmic inclusion bodies and in the cytoplasm of infected cells. J. Gen. Virol. 1998, 79, 2319-2323.

171. Mangrauthia, S.K.; Jain, R.K.; Praveen, S. Sequence motifs comparisons establish a functional portrait of a multifunctional protein hc-pro from papaya ringspot potyvirus. J. Plant Biochem. Biotechnol. 2008, 17, 201-204.

172. Plisson, C.; Drucker, M.; Blanc, S.; German-Retana, S.; Le Gall, O.; Thomas, D.; Bron, P. Structural characterization of hc-pro, a plant virus multifunctional protein. J. Biol. Chem. 2003, 278, 23753-23761.

173. Soitamo, A.J.; Jada, B.; Lehto, K. Hc-pro silencing suppressor significantly alters the gene expression profile in tobacco leaves and flowers. BMC Plant Biol. 2011, 11.

174. Wu, H.W.; Lin, S.S.; Chen, K.C.; Yeh, S.D.; Chua, N.H. Discriminating mutations of hc-pro of zucchini yellow mosaic virus with differential effects on small rna pathways involved in viral pathogenicity and symptom development. Mol. Plant-Microbe Interact. 2010, 23, 17-28.

175. Zheng, H.Y.; Yan, F.; Lu, Y.W.; Sun, L.Y.; Lin, L.; Cai, L.; Hou, M.S.; Chen, J.P. Mapping the self-interacting domains of tumv hc-pro and the subcellular localization of the protein. Virus Genes 2011, 42, 110-116.

176. Hjulsager, C.K.; Olsen, B.S.; Jensen, D.M.K.; Cordea, M.I.; Krath, B.N.; Johansen, I.E.; Lund, O.S. Multiple determinants in the coding region of pea seed-borne mosaic virus p3 are involved in virulence against sbm-2 resistance. Virology 2006, 355, 52-61.

177. Langenberg, W.G.; Zhang, L.Y. Immunocytology shows the presence of tobacco etch virus p3 protein in nuclear inclusions. J. Struct. Biol. 1997, 118, 243-247.

178. Hjulsager, C.K.; Lund, O.S.; Johansen, I.E. A new pathotype of pea seedborne mosaic virus explained by properties of the p3-6k1-and viral genome-linked protein (vpg)-coding regions. Mol. Plant-Microbe Interact. 2002, 15, 169-171.

179. Waltermann, A.; Maiss, E. Detection of $6 \mathrm{k} 1$ as a mature protein of $6 \mathrm{kda}$ in plum pox virusinfected nicotiana benthamiana. J. Gen. Virol. 2006, 87, 2381-2386.

180. Wei, T.Y.; Zhang, C.W.; Hong, J.A.; Xiong, R.Y.; Kasschau, K.D.; Zhou, X.P.; Carrington, J.C.; Wang, A.M. Formation of complexes at plasmodesmata for potyvirus intercellular movement is mediated by the viral protein p3n-pipo. PLoS Pathog. 2010, 6.

181. Riedel, D.; Lesemann, D.E.; Maiss, E. Ultrastructural localization of nonstructural and coat proteins of 19 potyviruses using antisera to bacterially expressed proteins of plum pox potyvirus. Arch. Virol. 1998, 143, 2133-2158.

182. Voloudakis, A.E.; Malpica, C.A.; Aleman-Verdaguer, M.E.; Stark, D.M.; Fauquet, C.M.; Beachy, R.N. Structural characterization of tobacco etch virus coat protein mutants. Arch. Virol. 2004, 149, 699-712.

183. Hema, M.; Reddy, C.V.S.; Savithri, H.S.; Sreenivasulu, P. Assembly of recombinant coat protein of sugarcane streak mosaic virus into potyvirus-like particles. Indian J. Exp. Biol. 2008, 46, 793-796. 
184. Atanasoff, D. Plum pox. A new virus disease. In Yearbook university of sofia, University of Sofia, F.o.A. Ed. Sofia, 1932; Vol. 11, pp 49-69.

185. Atanasoff, D. Mosaic of stone fruits. Phytopathology 1935, 8.

186. Candresse, T.; Svanella-Dumas, L.; Gentit, P.; Caglayan, K.; Cevik, B. First report of the presence of plum pox virus rec strain in turkey. Plant Dis. 2007, 91, 331-331.

187. Myrta, A.; Rwahnih, M.A.; Savino, V. Presence of a recombinant isolate of plum pox virus in apulia. J. Plant Pathol. 2005, 87, 127-130.

188. Snover-Clift, K.L.; Clement, P.A.; Jablonski, R.; Mungari, R.J.; Mavrodieva, V.A.; Negi, S.; Levy, L. First report of plum pox virus on plum in new york state. Plant Dis. 2007, 91, 15121512.

189. Zagrai, I.; Gaboreanu, I.; Ferencz, B.; Zagrai, L.; Pamfil, D.; Popescu, O.; Ravelonandro, M.; Capote, N.; Kovacs, K. First detection and molecular caracterization of plum pox virus recombinant strain in romania. In Bulletin of the university of agricultural sciences and veterinary medicine, vol 62, 2006: Animal husbandry and biotechnologies, 2006; pp 291-298.

190. Thompson, D.; Varga, A.; De Costa, H.; Birch, C.; Glasa, M.; James, D. First report of plum pox virus recombinant strain on prunus spp. In canada. Plant Dis. 2009, 93, 674-674.

191. Kamenova, I.; Dallot, S.; Bozkova, V.; Milusheva, S. First report of the plum pox virus recombinant strain on peach in bulgaria. Plant Dis. 2011, 95, 1320-1321.

192. Cambra, M.; Capote, N. Plum pox virus (ppv) in kazakhstan. EPPO Bull. 2006, 36, $210-211$.

193. Navratil, M.; Safarova, D.; Karesova, R.; Petrzik, K. First incidence of plum pox virus on apricot trees in china. Plant Dis. 2005, 89, 338-338.

194. Dal Zotto, A.; Ortego, J.M.; Raigon, J.M.; Caloggero, S.; Rossini, M.; Ducasse, D.A. First report in argentina of plum pox virus causing sharka disease in prunus. Plant Dis. 2006, 90, 523-523.

195. Capote, N.; Cambra, M. Plum pox virus (ppv) in pakistan. EPPO Bull. 2006, 36, 212-212.

196. Maejima, K.; Hoshi, H.; Hashimoto, M.; Himeno, M.; Kawanishi, T.; Komatsu, K.; Yamaji, Y.; Hamamoto, H.; Namba, S. First report of plum pox virus infecting japanese apricot (prunus mume sieb. Et zucc.) in japan. J. Gen. Plant Pathol. 2010, 76, 229-231.

197. Kolber, M.; Nemeth, M.; Chernets, A.; Kalashian, Y.; Dulic-Markovic, I.; Glasa, M.; Isac, M.; Kriska, B.; Malinowski, T.; Zawadzka, B. et al. Current situation of plum pox disease on stone fruit species in middle and eastern europe. In Proceedings of the 18th international symposium on virus \& virus-like diseases of temperate fruit crops - top fruit diseases, vols 1 and 2, INTERNATIONAL SOCIETY HORTICULTURAL SCIENCE: LEUVEN 1, 2001; pp 73-78.

198. Mikec, I.; Kajić, V.; Križanac, I. Plum pox virus (ppv) in croatia. EPPO Bull. 2006, 36, $207-$ 207.

199. Mikec, I.; Kajic, V.; Krajacic, M.; Skoric, D. Occurrence and distribution of plum pox virus in croatia. In Proceedings of the twentieth international symposium on virus and virus-like diseases of temperate fruit crops - fruit tree diseases, 2008; pp 193-196.

200. Isac, M.; Zagrai, I. Plum pox virus (ppv) in romania. EPPO Bull. 2006, 36, 213-213.

201. Varveri, C. Plum pox virus (ppv) in greece. EPPO Bull. 2006, 36, 209-210.

202. Navrátil, M. Plum pox virus (ppv) in the czech republic. EPPO Bull. 2006, 36, 208-208.

203. Jarausch, W. Plum pox virus (ppv) in germany. EPPO Bull. 2006, 36, 209-209. 
204. Milusheva, S.; Kamenova, I.; Stoev, A. Plum pox virus (ppv) in bulgaria. EPPO Bull. 2006, 36, 206-206.

205. Kölber, M. Plum pox virus (ppv) in hungary. EPPO Bull. 2006, 36, 210-210.

206. Prichodko, Y. Plum pox virus (ppv) in russia. EPPO Bull. 2006, 36, 213-213.

207. Malinowski, T. Plum pox virus (ppv) in poland. EPPO Bull. 2006, 36, 212-213.

208. EPPO, Plum pox potyvirus. EPPO Bull. 2004, 34, 247-256.

209. Dulic-Markovic, I.; Jevremovic, D. Plum pox virus (ppv) in serbia. EPPO Bull. 2006, 36, $213-$ 214.

210. Glasa, M. Plum pox virus (ppv) in slovakia. EPPO Bull. 2006, 36, 214-214.

211. Ortego, J.; Dal Zotto, A.; Caloggero, S.; Raigón, J.M.; Gasparini, M.L.; Ojeda, M.E.; Ducasse, D.A. Current status of ppv worldwide - plum pox virus (ppv) in argentina. EPPO Bull. 2006, 36, 205-205.

212. Stamo, B.; Myrta, A. Current status of ppv worldwide - plum pox virus (ppv) in albania. EPPO Bull. 2006, 36, 205-205.

213. Akbas, B.; Degirmenci, K.; Ciftci, O.; Kaya, A.; Yurtmen, M.; Uzunogullari, N.; Celik, N.; Torkolmez, S. Update on plum pox virus distribution in turkey. Phytopathologia Mediterranea 2011, 50, 75-83.

214. Di Terlizzi, B.; Boscia, D. Plum pox virus (ppv) in italy. EPPO Bull. 2006, 36, 210-210.

215. Ortego, J.; Zotto, A.D.; Caloggero, S.; Raigón, J.M.; Gasparini, M.L.; Ojeda, M.E.; Ducasse, D.A. Plum pox virus (ppv) in argentina. EPPO Bull. 2006, 36, 205-205.

216. Kalashian, Y.; Chernets, A. Plum pox virus (ppv) in moldova. EPPO Bull. 2006, 36, 211-211.

217. Youssef, S.A.; Shalaby, A. Plum pox virus (ppv) in egypt. EPPO Bull. 2006, 36, 208-208.

218. Norkus, T.; Staniulis, J.; Zizyte, M.; Melnyk, M.; Yusko, L.; Snihur, H.; Budzanivska, I.; Polischuk, V. Molecular identification of plum pox virus isolates from lithuania and ukraine. Zemdirbyste-Agriculture 2008, 95, 277-285.

219. Wang, A.; Sanfacon, H.; Stobbs, L.W.; James, D.; Thompson, D.; Svircev, A.M.; Brown, D.C.W. Plum pox virus in canada: Progress in research and future prospects for disease control. Can. J. Plant Pathol.-Rev. Can. Phytopathol. 2006, 28, 182-196.

220. Blystad, D.R.; Munthe, T. Plum pox virus (ppv) in norway. EPPO Bull. 2006, 36, 212-212.

221. Zamharir, M.G.; Bashir, N.S.; Khakvar, R. Plum pox virus (ppv) in iran. EPPO Bull. 2006, 36, 210-210.

222. Speich, P. Plum pox virus (ppv) in france. EPPO Bull. 2006, 36, 208-209.

223. Marn, M.V.; Mavric, I. Plum pox virus (ppv) in slovenia. EPPO Bull. 2006, 36, 214-214.

224. Kondratenko, P.; Udovychenko, V. Plum pox virus (ppv) in ukraine. EPPO Bull. 2006, 36, $217-$ 217.

225. Mumford, R.A. Plum pox virus (ppv) in the united kingdom. EPPO Bull. 2006, 36, 217-217.

226. Ismaeil, F. Plum pox virus (ppv) in syria. EPPO Bull. 2006, 36, 216-216.

227. Levy, L. Plum pox virus (ppv) in the united states of america. EPPO Bull. 2006, 36, 217-218.

228. Caglayan, K. Plum pox virus (ppv) in turkey. EPPO Bull. 2006, 36, 216-217.

229. Cambra, M.A.; Serra, J.; Cano, A.; Cambra, M. Plum pox virus (ppv) in spain. EPPO Bull. 2006, 36, 215-215.

230. Muñoz, M.; Collao, M. Plum pox virus (ppv) in chile. EPPO Bull. 2006, 36, 207-207. 
231. Matić, S.; Durić, G.; Myrta, A. Current status of ppv worldwide - plum pox virus (ppv) in bosnia and herzegovina. EPPO Bull. 2006, 36, 205-206.

232. Staniulis, J. Plum pox virus (ppv) in lithuania. EPPO Bull. 2006, 36, 211-211.

233. Verhoeven, J.T.J.; Roenhorst, J.W.; Jongedijk, G.P. Plum pox virus (ppv) in the netherlands. EPPO Bull. 2006, 36, 211-212.

234. Boulila, M.; Ravelonandro, M. Plum pox virus (ppv) in tunisia. EPPO Bull. 2006, 36, 216-216.

235. Ramel, M.E.; Gugerli, P.; Bünter, M. Plum pox virus (ppv) in switzerland. EPPO Bull. 2006, 36, $215-216$.

236. Lemmetty, A. Plum pox virus (ppv) in finland. EPPO Bull. 2006, 36, 208-208.

237. Choueiri, E. Plum pox virus (ppv) in lebanon. EPPO Bull. 2006, 36, 211-211.

238. Navratil, M.; Safarova, D.; Karesova, R.; Petrzik, K. Plum pox virus (ppv) in china. EPPO Bull. 2006, 36, 207-207.

239. Reyes, F.; Fiore, N.; Reyes, M.A.; Sepulveda, P.; Paredes, V.; Prieto, H. Biological behavior and partial molecular characterization of six chilean isolates of plum pox virus. Plant Dis. 2003, 87, $15-20$.

240. Manachini, B.; Casati, P.; Aliverti, I.; Cinanni, L. Transmission of ppv-m to prunus persica by brachycaudus schwartzi and phorodon humuli (hem. aphididae). J. Appl. Entomol. 2004, 128, 677-680.

241. Zawadzka, B.; Rozpara, E.; Grzyb, Z. The response of some new plum cultivars to plum pox virus (ppv). In Vi international symposium on plum and prune genetics, breeding and pomology, INTERNATIONAL SOCIETY HORTICULTURAL SCIENCE: LEUVEN 1, 1998; pp 81-85.

242. Paprstein, F.; Karesova, R.; Navratil, M. Evaluation of ppv symptoms on plum fruits. In Proceedings of the eighth international symposium on plum and prune genetics, breeding and pomology, 2007; pp 255-257.

243. Varveri, C.; Zintzaras, E.; Dimou, D.; Di Terlizzi, B. Monitoring and spatiotemporal analysis of ppv-m spread in two apricot orchards in southern greece. In Proceedings of the 18th international symposium on virus \& virus-like diseases of temperate fruit crops - top fruit diseases, vols 1 and 2, INTERNATIONAL SOCIETY HORTICULTURAL SCIENCE: LEUVEN 1, 2001; pp 129-133.

244. Clemente-Moreno, M.J.; Piqueras, A.; Hernandez, J.A. Implication of peroxidase activity in development of healthy and ppv-infected micropropagated gf305 peach plants. Plant Growth Regul. 2011, 65, 359-367.

245. Pacheco, R.; Garcia-Marcos, A.; Manzano, A.; de Lacoba, M.G.; Camanes, G.; Garcia-Agustin, P.; Diaz-Ruiz, J.R.; Tenllado, F. Comparative analysis of transcriptomic and hormonal responses to compatible and incompatible plant-virus interactions that lead to cell death. Mol. PlantMicrobe Interact. 2012, 25, 709-723.

246. Nagyova, A.; Kamencayova, M.; Glasa, M.; Subr, Z.W. The 3'-proximal part of the plum pox virus 1 gene determinates the symptom expression in two herbaceous host plants. Virus Genes 2012, 44, 505-512.

247. Varveri, C.; Vassilakos, N. Preliminary biological and molecular characterization of mild ppv isolates naturally induced in $\mathrm{n}$-benthamiana plants. In Proceedings of the twentieth international 
symposium on virus and virus-like diseases of temperate fruit crops - fruit tree diseases, INTERNATIONAL SOCIETY HORTICULTURAL SCIENCE: LEUVEN 1, 2008; pp 249-253.

248. Sutic, D.; Jordovic, M.; Rankovic, M.; Festi, H. In Comparative studies of some sharka virus isolates. Proceedings of the VIII Symposium sur les Maladies a Virus des Arbres Frutiers. Annales de Phytopathologie, 1971; 1971; pp 185-194.

249. James, D.; Varga, A.; Thompson, D.; Hayes, S. Detection of a new and unusual isolate of plum pox virus in plum (prunus domestica). Plant Dis. 2003, 87, 1119-1124.

250. Serce, C.U.; Candresse, T.; Svanella-Dumas, L.; Krizbai, L.; Gazel, M.; Caglayan, K. Further characterization of a new recombinant group of plum pox virus isolates, ppv-t, found in orchards in the ankara province of turkey. Virus Res. 2009, 142, 121-126.

251. Matic, S.; Elmaghraby, I.; Law, V.; Varga, A.; Reed, C.; Myrta, A.; James, D. Serological and molecular characterization of isolates of plum pox virus strain el amar to better understand its diversity, evolution, and unique geographical distribution. Journal of Plant Pathology 2011, 93, 303-310.

252. Candresse, T.; Macquaire, G.; Lanneau, M.; Bousalem, M.; Wetze, T.; Quiot-Douine, L.; Quiot, J.B.; Dunez, J. Detection of plum pox potyvirus and analysis of its molecular variability using immunocapture-pcr1. EPPO Bull. 1994, 24, 585-594.

253. Glasa, M.; Malinowski, T.; Predajna, L.; Pupola, N.; Dekena, D.; Michalczuk, L.; Candresse, T. Sequence variability, recombination analysis, and specific detection of the w strain of plum pox virus. Phytopathology 2011, 101, 980-985.

254. Glasa, M.; Matisova, J.; Kudela, O. Characterization of plum pox virus isolates from slovakia. Acta Virol. 1998, 42, 226-229.

255. Navratil, M.; Simonova, V.; Fialova, R.; Valova, P. Molecular variability of czech plum pox virus isolates. Acta Virol. 1998, 42, 254-256.

256. Navratil, M.; Simonova, V.; Paprstein, F.; Karesova, R. Detection and serological identification of plum pox virus isolates in the czech republic. In 17th international symposium on virus and virus-like diseases of temperate fruit crops: Fruit tree diseases, vols 1 and 2, 1998; pp 373-378.

257. Al Rwahnih, M.; Boscia, D.; Myrta, A.; Di Terlizzi, B. First record of plum pox virus in jordan. In Proceedings of the 18th international symposium on virus \& virus-like diseases of temperate fruit crops - top fruit diseases, vols 1 and 2, 2001; pp 141-144.

258. Kamenova, I.; Milusheva, S.; Borisova, A.; Stoev, A.; Myrta, A. Typing of plum pox virus isolates in bulgaria: Preliminary results. Biotechnol. Biotechnol. Equip. 2002, 16, 10-13.

259. Bianco, P.A.; Aliverti, I.; Casati, P.; Belli, G.; Comes, S.; Fanigliulo, A.; Crescenzi, A. Detection and characterization of plum pox virus isolates in lombardia and veneto regions (italy). In Proceedings of the xixth international symposium on virus and virus-like diseases of temperate fruit crops: Fruit tree diseases, 2004; pp 165-169.

260. Cambra, M.; Gorris, M.T.; Capote, N.; Asensio, M.; Martinez, M.C.; Bertolini, E.; Collado, C.; de Mendoza, A.H.; Mataix, E.; Lopez, A. Epidemiology of plum pox virus in japanese plums in spain. In Proceedings of the xixth international symposium on virus and virus-like diseases of temperate fruit crops: Fruit tree diseases, 2004; pp 195-200.

261. Jarausch, W.; Bassler, A.; Molla, N.; Krezal, G. First detection and molecular characterisation of ppv-m strains in plum orchards in south-western germany. In Proceedings of the xixth 
international symposium on virus and virus-like diseases of temperate fruit crops: Fruit tree diseases, 2004; pp 159-164.

262. Marn, M.V.; Mavric, I. Current status of sharka disease in slovenia. In Proceedings of the xixth international symposium on virus and virus-like diseases of temperate fruit crops: Fruit tree diseases, 2004; pp 245-249.

263. Dallot, S.; Boeglin, M.; Labonne, G. Spatial pattern and genetic structure of $\mathrm{ppv}-\mathrm{m}$ in a delimited area of stone fruit orchards in southern france. In Proceedings of the twentieth international symposium on virus and virus-like diseases of temperate fruit crops - fruit tree diseases, 2008; pp 235-242.

264. Dallot, S.; Kamenova, I.; Glasa, M.; Pittnerova, S.; Kominek, P.; Paunovic, S.; Jevremovic, D.; Virscek-Marn, M.; Plesko, I.M.; Milusheva, S. Prevalence and genetic structure of ppv-m in six european countries. In Proceedings of the twentieth international symposium on virus and viruslike diseases of temperate fruit crops - fruit tree diseases, 2008; pp 227-234.

265. Kajic, V.; Cerni, S.; Krajacic, M.; Mikec, I.; Skoric, D. Molecular typing of plum pox virus isolates in croatia. J. Plant Pathol. 2008, 90, 9-13.

266. Zagrai, L.; Zagrai, I.; Ferencz, B.; Gaboreanu, I.; Kovacs, K.; Petricele, I.; Popescu, O.; Pamfil, D.; Capote, N. Serological and molecular typing of plum pox virus isolates in the north of romania. J. Plant Pathol. 2008, 90, 41-46.

267. Zagrai, I.; Zagrai, L.; Ferencz, B.; Petricele, I.; Pamfil, D.; Popescu, O.; Briciu, A.; Festila, A. Serological and molecular typing of plum pox virus isolates in the transylvania, romania. Not. Bot. Horti Agrobot. Cluj-Na. 2009, 37, 265-272.

268. Capote, N.; Cambra, M.A.; Botella, P.; Gorris, M.T.; Martinez, M.C.; Lopez-Quilez, A.; Cambra, M. Detection, characterization, epidemiology and eradication of plum pox virus marcus type in spain. J. Plant Pathol. 2010, 92, 619-628.

269. Zagrai, I.; Zagrai, L.; Preda, S.; Kelemen, B.; Petricele, I.; Popescu, O.; Pamfil, D.; Isac, M. Genetic diversity of plum pox virus isolates in muntenia, romania. Rom. Biotech. Lett. 2010, 15, 5303-5309.

270. Dallot, S.; Glasa, M.; Jevremovic, D.; Kamenova, I.; Paunovic, S.; Labonne, G. Mediterranean and central-eastern european countries host viruses of two different clades of plum pox virus strain m. Arch. Virol. 2011, 156, 539-542.

271. Myrta, A.; Palmisano, F.; Pulaj, B.; Susuri, L.R.; Boscia, D. Incidence of plum pox virus and its strains in kosovo. J. Plant Pathol. 2011, 93, 725-728.

272. Rosales, M.; Hinrichsen, P.; Herrera, G. Molecular characterization of plum pox virus isolated from apricots, plums and peaches in chile. In 17th international symposium on virus and viruslike diseases of temperate fruit crops: Fruit tree diseases, vols 1 and 2, INTERNATIONAL SOCIETY HORTICULTURAL SCIENCE: LEUVEN 1, 1998; pp 401-405.

273. Rochon, D.; Theilmann, J.; James, D.; Reade, R.; Yang, L.; Upton, C. Partial molecular characterization of plum pox virus isolates occurring in canada. Can. J. Plant Pathol.-Rev. Can. Phytopathol. 2003, 25, 198-208.

274. Marie-Jeanne, V.; Thebaud, G.; Peyre, J.; Labonne, G. Spatially arranged diversity of plum pox virus (ppv) isolates in a cluster of orchards in southern france. In Proceedings of the xixth international symposium on virus and virus-like diseases of temperate fruit crops: Fruit tree 
diseases, INTERNATIONAL SOCIETY HORTICULTURAL SCIENCE: LEUVEN 1, 2004; pp 213-215.

275. Elibuyuk, I.O. Current situation of sharka disease in ankara, turkey. Phytoparasitica 2004, 32, 417-420.

276. Theilmann, J.; Yang, L.; Rochon, D. Sequence analysis of isolates of the canadian plum pox virus, and comparisons to isolates from europe and the united states. Can. J. Plant Pathol.-Rev. Can. Phytopathol. 2006, 28, 144-151.

277. Matic, S.; Al-Rwahnih, M.; Myrta, A. Diversity of plum pox virus isolates in bosnia and herzegovina. Plant Pathol. 2006, 55, 11-17.

278. Gadiou, S.; Safarova, D.; Navratil, M. Genetic variability of plum pox virus isolates in the czech republic. Eur. J. Plant Pathol. 2008, 121, 513-517.

279. Zagrai, I.; Zagrai, L.; Preda, S.; Kelemen, B.; Petricele, I.; Popescu, O.; Pamfil, D.; Isac, M. Genetic diversity of plum pox virus isolates in muntenia, romania. Rom. Biotech. Lett. 2011, 15, 5303-5309.

280. Glasa, M.; Paunovic, S.; Jevremovic, D.; Myrta, A.; Pittnerova, S.; Candresse, T. Analysis of recombinant plum pox virus (ppv) isolates from serbia confirms genetic homogeneity and supports a regional origin for the ppv-rec subgroup. Arch. Virol. 2005, 150, 2051-2060.

281. Navratil, M.; Safarova, D.; Gadiou, S.; Franova, J.; Kucerova, J.; Talacko, L. The partial molecular characterization of plum pox virus infecting sweet cherry trees in the czech republic. In Proceedings of the twentieth international symposium on virus and virus-like diseases of temperate fruit crops - fruit tree diseases, INTERNATIONAL SOCIETY HORTICULTURAL SCIENCE: LEUVEN 1, 2008; pp 203-208.

282. Wetzel, T.; Candresse, T.; Ravelonandro, M.; Delbos, R.P.; Mazyad, H.; Aboulata, A.E.; Dunez, J. Nucleotide-sequence of the 3'-terminal region of the rna of the elamar strain of plum pox potyvirus. J. Gen. Virol. 1991, 72, 1741-1746.

283. Abdel-Ghaffar, M.H.; El-Nasr, M.A.A.; Hari, V. Studies on an apricot strain of plum pox potyvirus isolated from el amar, egypt. In 17th international symposium on virus and virus-like diseases of temperate fruit crops: Fruit tree diseases, vols 1 and 2, 1998; pp 385-391.

284. Aboul-Ela, A.; Aboul-Ata, A.E.; Mazyad, H.M. Plum pox potyvirus situation in egyptian stone fruit trees. In International symposium on apricot culture, vols 1 and 2, INTERNATIONAL SOCIETY HORTICULTURAL SCIENCE: LEUVEN 1, 1999; pp 745-751.

285. Myrta, A.; Varga, A.; James, D. The complete genome sequence of an el amar isolate of plum pox virus (ppv) and its phylogenetic relationship to other ppv strains. Arch. Virol. 2006, 151, 1189-1198.

286. Matic, S.; Elmaghraby, I.; Law, V.; Varga, A.; Reed, C.; Myrta, A.; James, D. Serological and molecular characterization of isolates of plum pox virus strain el amar to better understand its diversity, evolution, and unique geographical distribution. J. Plant Pathol. 2011, 93, 303-310.

287. Nemchinov, L.; Hadidi, A.; Kolber, M.; Nemeth, M. Molecular evidence for the occurrence of plum pox virus - cherry subgroup in hungary. In 17th international symposium on virus and virus-like diseases of temperate fruit crops: Fruit tree diseases, vols 1 and 2, INTERNATIONAL SOCIETY HORTICULTURAL SCIENCE: LEUVEN 1, 1998; pp 503-508. 
288. Nemchinov, L.; Hadidi, A.; Maiss, E.; Cambra, M.; Candresse, T.; Damsteegt, V. Sour cherry strain of plum pox potyvirus (ppv): Molecular and serological evidence for a new subgroup of ppv strains. Phytopathology 1996, 86, 1215-1221.

289. Crescenzi, A.; dAquino, L.; Comes, S.; Nuzzaci, M.; Piazzolla, P.; Boscia, D.; Hadidi, A. Characterization of the sweet cherry isolate of plum pox potyvirus. Plant Dis. 1997, 81, 711714.

290. Isac, M.; Plopa, C.; Calinescu, M.; Myrta, A. Detection of the viral diseases presently with the stone fruit species in romania. In Proceedings of the twentieth international symposium on virus and virus-like diseases of temperate fruit crops - fruit tree diseases, 2008; pp 59-63.

291. Schneider, W.L.; Damsteegt, V.D.; Gildow, F.E.; Stone, A.L.; Sherman, D.J.; Levy, L.E.; Mavrodieva, V.; Richwine, N.; Welliver, R.; Luster, D.G. Molecular, ultrastructural, and biological characterization of pennsylvania isolates of plum pox virus. Phytopathology 2011, $101,627-636$.

292. Damsteegt, V.D.; Stone, A.L.; Schneider, W.L.; Luster, D.G.; Gildow, F.E. Potential prunus host range of ppv-penn isolates by aphid transmission. In Proceedings of the xixth international symposium on virus and virus-like diseases of temperate fruit crops: Fruit tree diseases, INTERNATIONAL SOCIETY HORTICULTURAL SCIENCE: LEUVEN 1, 2004; pp 201-205.

293. James, D.; Varga, A. Nucleotide sequence analysis of plum pox virus isolate w3174: Evidence of a new strain. Virus Res. 2005, 110, 143-150.

294. Riechmann, J.L.; Lain, S.; Garcia, J.A. Highlights and prospects of potyvirus molecular-biology. J. Gen. Virol. 1992, 73, 1-16.

295. Salvador, B.; García, J.A.; Simón-Mateo, C. Causal agent of sharka disease: Plum pox virus genome and function of

gene products. EPPO Bull. 2006, 36, 229-238.

296. Teycheney, P.Y.; Tavert, G.; Delbos, R.; Ravelonandro, M.; Dunez, J. The complete nucleotidesequence of plum pox virus-rna (strain-d). Nucleic Acids Res. 1989, 17, 10115-10116.

297. Riechmann, J.L.; Lain, S.; Garcia, J.A. Identification of the initiation codon of plum pox potyvirus genomic rna. Virology 1991, 185, 544-552.

298. Khan, M.A.; Goss, D.J. Poly(a)-binding protein increases the binding affinity and kinetic rates of interaction of viral protein linked to genome with translation initiation factors eifiso $4 \mathrm{f}$ and eifiso4f.4b complex. Biochemistry 2012, 51, 1388-1395.

299. Alvarez, V.; Ducasse, D.A.; Biderbost, E.; Nome, S.F. Sequencing and characterization of the coat protein and 3' non-coding region of a new sweet potato potyvirus. Arch. Virol. 1997, 142, $1635-1644$.

300. Colinet, D.; Kummert, J.; Lepoivre, P. Evidence for the assignment of two strains of splv to the genus potyvirus based on coat protein and 3' non-coding region sequence data. Virus Res. 1997, 49, 91-100.

301. Carrington, J.C.; Freed, D.D. Cap-independent enhancement of translation by a plant potyvirus 5' nontranslated region. J. Virol. 1990, 64, 1590-1597.

302. Kneller, E.L.P.; Rakotondrafara, A.M.; Miller, W.A. Cap-independent translation of plant viral rnas. Virus Res. 2006, 119, 63-75. 
303. SimonBuela, L.; Guo, H.S.; Garcia, J.A. Cap-independent leaky scanning as the mechanism of translation initiation of a plant viral genomic rna. J. Gen. Virol. 1997, 78, 2691-2699.

304. Fanigliulo, A.; Comes, S.; Maiss, E.; Piazzolla, P.; Crescenzi, A. The complete nucleotide sequence of plum pox virus isolates from sweet (ppv-swc) and sour (ppv-soc) cherry and their taxonomic relationships within the species. Arch. Virol. 2003, 148, 2137-2153.

305. Glasa, M.; Marie-Jeanne, V.; Moury, B.; Kudela, O.; Quiot, J.B. Molecular variability of the p3$6 \mathrm{k}(1)$ genomic region among geographically and biologically distinct isolates of plum pox virus. Arch. Virol. 2002, 147, 563-575.

306. Poncarova, Z.; Kominek, P. Restriction fragment length polymorphism differentiation of plum pox virus isolates. Acta Virol. 1998, 42, 268-269.

307. SimonBuela, L.; Guo, H.S.; Garcia, J.A. Long sequences in the 5 ' noncoding region of plum pox virus are not necessary for viral infectivity but contribute to viral competitiveness and pathogenesis. Virology 1997, 233, 157-162.

308. Simon-Buela, L.; Osaba, L.; Garcia, J.A.; Lopez-Moya, J.J. Preservation of 5 '-end integrity of a potyvirus genomic rna is not dependent on template specificity. Virology 2000, 269, 377-382.

309. Fernandez-Calvino, L.; Lopez-Abella, D.; Lopez-Moya, J.J.; Fereres, A. Comparison of potato virus $\mathrm{y}$ and plum pox virus transmission by two aphid species in relation to their probing behavior. Phytoparasitica 2006, 34, 315-324.

310. Fos, A.; Massonie, G. Experimental transmission of plum pox virus by brachycaudus-persicae passerini. Agronomie 1993, 13, 515-518.

311. Gildow, F.E.; Damsteegt, V.D.; Stone, A.L.; Schneider, W.L.; Luster, D.G.; Levy, L. Transmission of three north american isolates of plum pox virus: Identification of aphid vectors and species-specific transmission from infected stone fruits. In Proceedings of the xixth international symposium on virus and virus-like diseases of temperate fruit crops: Fruit tree diseases, 2004; pp 207-211.

312. Glasa, M.; Boeglin, M.; Labonne, G. Aphid transmission of natural recombinant plum pox virus isolates to different prunus ssp - a contribution for understanding the epidemiology of an atypical ppv. In Proceedings of the xixth international symposium on virus and virus-like diseases of temperate fruit crops: Fruit tree diseases, INTERNATIONAL SOCIETY HORTICULTURAL SCIENCE: LEUVEN 1, 2004; pp 217-220.

313. Lopezmoya, J.J.; Canto, T.; Diazruiz, J.R.; Lopezabella, D. Transmission by aphids of a naturally non-transmissible plum pox virus isolate with the aid of potato-virus-y helper component. J. Gen. Virol. 1995, 76, 2293-2297.

314. Paprstein, F.; Karesova, R.; Navratil, M. Results of plum pox virus transmission into germplasm of plums. In Vi international symposium on plum and prune genetics, breeding and pomology, INTERNATIONAL SOCIETY HORTICULTURAL SCIENCE: LEUVEN 1, 1998; pp 279-282.

315. Milusheva, S.; Gercheva, P.; Bozhkova, V.; Kamenova, I. Experiments on transmission of plum pox virus through prunus seeds. J. Plant Pathol. 2008, 90, 23-26.

316. Glasa, M.; Hriovsky, I.; Kudela, O. Evidence for non-transmission of plum pox virus by seed in infected plum and myrobalan. Biologia 1999, 54, 481-484.

317. Schimanski, H.H.; Gruntzig, M.; Fuchs, E. Non-transmission of the plum pox virus in plum and apricot seed source clones. Zentralblatt Fur Mikrobiologie 1988, 143, 121-123. 
318. Dicenta, F.; Audergon, J.M. Localization of plum pox virus in apricot stem and petiole tissues by tissue printing onto nitrocellulose membrane. Ann. Appl. Biol. 1995, 126, 105-110.

319. Hoffmann, A.; Stockert, T.; Hartmann, W.; Stosser, R. Localization of plum pox virus (ppv, sharka) in plum (prunus domestica 1.) using tissue print immunoblotting (tpib). J. Plant Dis. Prot. 1997, 104, 411-414.

320. Rubio, M.; Gosalvez, B.; Hernandez, J.A.; Sanchez-Navarro, J.A.; Pallas, V. Localization of coat protein and nucleic acid of plum pox virus in prunus petiole and stem tissues. In Proceedings of the xixth international symposium on virus and virus-like diseases of temperate fruit crops: Fruit tree diseases, INTERNATIONAL SOCIETY HORTICULTURAL SCIENCE: LEUVEN 1, 2004; pp 295-300.

321. Rubio, M.; Martinez-Gomez, P.; Dicenta, F. Study of long-distance movement of plum pox virus (sharka) as an alternative resistance-evaluation method in prunus. Sci. Hortic. 2008, 118, $223-227$.

322. Dicenta, F.; Martinez-Gomez, P.; Rubio, M.; Audergon, J.M. Localisation and movement of plum pox virus in apricot stem tissues. Ann. Appl. Biol.

2003, 142, 99-105.

323. Quiot, J.B.; Tab, F.; Labonne, G.; Adamolle, C.; Boeglin, M. Location of plum pox virus in peach and apricot trees. In Proceedings of the xiith ishs symposium on apricot culture and decline, vols 1 and 2, INTERNATIONAL SOCIETY HORTICULTURAL SCIENCE: LEUVEN 1, 2006; pp 489-492.

324. Elouaghlidi, F.; Sautter, C. Immunofluorescence localization of plum pox virus and prunus necrotic ringspot virus in tissue-sections of prunus-cerasus and prunus-juxa. J. Plant Dis. Prot. 1988, 95, 70-76.

325. Hernandez, J.A.; Talavera, J.M.; Martinez-Gomez, P.; Dicenta, F.; Sevilla, F. Response of antioxidative enzymes to plum pox virus in two apricot cultivars. Physiol. Plant. 2001, 111, 313 321.

326. Visedo, G.; Fernandezpiqueras, J.; Garcia, J.A. Peroxidase isozyme analysis of factors involved in development of symptoms in nicotiana-clevelandii infected by plum pox virus. Physiol. Plant. 1991, 83, 165-169.

327. Visedo, G.; Fernandezpiqueras, J.; Garcia, J.A. Comparison among the isozyme profiles associated with ethrel treatments of leaves, and with senescence and plum pox virus-infection in chenopodium-foetidum. Physiol. Plant. 1991, 83, 159-164.

328. Hernandez, J.A.; Olmos, J.E.; Portillo, B.; Rubio, M.; Dicenta, F.; Martinez-Gomez, P. Effect of plum pox virus infection on photosynthesis and antioxidant enzyme activity in peach 'gf305'. In Proceedings of the xixth international symposium on virus and virus-like diseases of temperate fruit crops: Fruit tree diseases, INTERNATIONAL SOCIETY HORTICULTURAL SCIENCE: LEUVEN 1, 2004; pp 349-353.

329. Diaz-Vivancos, P.; Clemente-Moreno, M.J.; Rubio, M.; Olmos, E.; Garcia, J.A.; MartinezGomez, P.; Hernandez, J.A. Alteration in the chloroplastic metabolism leads to ros accumulation in pea plants in response to plum pox virus. J. Exp. Bot. 2008, 59, 2147-2160.

330. Hernandez, J.A.; Diaz-Vivancos, P.; Rubio, M.; Olmos, E.; Ros-Barcelo, A.; Martinez-Gomez, P. Long-term plum pox virus infection produces an oxidative stress in a susceptible apricot, prunus armeniaca, cultivar but not in a resistant cultivar. Physiol. Plant. 2006, 126, 140-152. 
331. Diaz-Vivancos, P.; Rubio, M.; Mesonero, V.; Martinez-Gomez, P.; Hernandez, J.A.; Periago, P.M. Effect of plum pox virus infection on the antioxidant capacity of leaf apoplast from apricot plants. In Proceedings of the xiiith international symposium on apricot breeding and culture, INTERNATIONAL SOCIETY HORTICULTURAL SCIENCE: LEUVEN 1, 2006; pp 119-122.

332. Diaz-Vivancos, P.; Rubio, M.; Mesonero, V.; Periago, P.M.; Barcelo, A.R.; Martinez-Gomez, P.; Hernandez, J.A. The apoplastic antioxidant system in prunus: Response to long-term plum pox virus infection. J. Exp. Bot. 2006, 57, 3813-3824.

333. Escalettes, V.S.L.; Hullot, C.; Wawrzy'nczak, D.; Mathieu, E.; Eyquard, J.P.; Le Gall, O.; Decroocq, V. Plum pox virus induces differential gene expression in the partially resistant stone fruit tree prunus armeniaca cv. Goldrich. Gene 2006, 374, 96-103.

334. Babu, M.; Griffiths, J.S.; Huang, T.S.; Wang, A. Altered gene expression changes in arabidopsis leaf tissues and protoplasts in response to plum pox virus infection. Bmc Genomics 2008, 9.

335. Wang, A.; Chapman, P.; Chen, L.; Stobbs, L.W.; Brown, D.C.W.; Brandle, J.E. A comparative survey, by expressed sequence tag analysis, of genes expressed in peach leaves infected with plum pox virus (ppv) and free from ppv. Can. J. Plant Pathol.-Rev. Can. Phytopathol. 2005, 27, 410-419.

336. Milosevic, T.; Milosevic, N. Plum pox virus as a stress factor in the one-year-old shoot and fruit growth and yield of plum cv. Stanley. Cereal Res. Commun. 2009, 37, 241-244.

337. Milosevic, T.M.; Glisic, I.P.; Milosevic, N.T.; Glisic, I.S. Plum pox virus as a stress factor in the vegetative growth, fruit growth and yield of plum (prunus domestica) cv. 'Cacanska rodna'. Eur. J. Plant Pathol. 2010, 126, 73-79.

338. Garcia-Ibarra, A.; Clemente-Moreno, M.J.; Barba-Espin, G.; Diaz-Vivancos, P.; Rubio, M.; Dicenta, F.; Martinez-Gomez, P.; Hernandez, J.A. Changes in the antioxidative metabolism induced by apple chlorotic leaf spot virus infection in peach [prunus persica (1.) batsch]. Environ. Exp. Bot. 2011, 70, 277-282.

339. Amari, K.; Diaz-Vivancos, P.; Pallas, V.; Amelia Sanchez-Pina, M.; Antonio Hernandez, J. Oxidative stress induction by prunus necrotic ringspot virus infection in apricot seeds. Physiol. Plant. 2007, 131, 302-310.

340. Clarke, S.F.; Guy, P.L.; Burritt, D.J.; Jameson, P.E. Changes in the activities of antioxidant enzymes in response to virus infection and hormone treatment. Physiol. Plant. 2002, 114, 157164.

341. Farkas, G.L.; Kiraly, Z.; Solymosy, F. Role of oxidative metabolism in the localization of plant viruses. Virology 1960, 12, 408-421.

342. Fodor, J.; Gullner, G.; Adam, A.L.; Barna, B.; Komives, T.; Kiraly, Z. Local and systemic responses of antioxidants to tobacco mosaic virus infection and to salicylic acid in tobacco - role in systemic acquired resistance. Plant Physiol. 1997, 114, 1443-1451.

343. Kiraly, L.; Barnaz, B.; Kiralyz, Z. Plant resistance to pathogen infection: Forms and mechanisms of innate and acquired resistance. J. Phytopathol. 2007, 155, 385-396.

344. Kröll, J. Experiments to verify the plum pox virus (ppv) by communicating it on chenopodium foetidum schrad. . Zentralbl. Bakteriol. Parasitenkd. Infektionskr. Hyg. 1975, 130, 226-231.

345. Kröll, J. Verification of the plum pox virus (ppv) using the tray test. Zentralbl. Bakteriol. Naturwiss. 1978, 133, 59-64. 
346. Glasa, M.; Matisova, J.; Hricovsky, I.; Kudela, O. Susceptibility of peach gf 305 seedlings and selected herbaceous plants to plum pox virus isolates from western slovakia. Acta Virol. 1997, 41, 341-344.

347. Polak, J. European spindle tree and common privet a new natural hosts of plum pox virus. In Proceedings of the 18th international symposium on virus \& virus-like diseases of temperate fruit crops - top fruit diseases, vols 1 and 2, 2001; pp 125-128.

348. Visedo, G.; Fernandezpiqueras, J.; Garcia, J.A. Isozyme profiles associated with the hypersensitive response of chenopodium-foetidum to plum pox virus-infection. Physiol. Plant. 1990, 78, 218-224.

349. Di Terlizzi, B.; Savino, V. Sanitary status and sanitation of stone fruit trees in south east italy. In Iobc/wprs and ishs international conference on integrated fruit production, proceedings of the meeting, 1996; pp 326-327.

350. Paprstein, F.; Karesova, R. Long term evaluation of plum cultivars artificially infected by ppv. In Proceedings of the 18th international symposium on virus \& virus-like diseases of temperate fruit crops - top fruit diseases, vols 1 and 2, 2001; pp 121-123.

351. James, D.; Thompson, D. Hosts and symptoms of plum pox virus: Ornamental and wild prunus species. EPPO Bull. 2006, 36, 222-224.

352. Rubio, M.; Martinez-Gomez, P.; Pinochet, J.; Dicenta, F. Evaluation of resistance to sharka (plum pox virus) of several prunus rootstocks. Plant Breed. 2005, 124, 67-70.

353. Martinez-Gomez, P.; Rubio, M.; Gambin, M.; Dicenta, F. Behaviour of six prunus rootstocks in presence of sharka (plum pox potyvirus). In Proceedings of the xiith ishs symposium on apricot culture and decline, vols 1 and 2, INTERNATIONAL SOCIETY HORTICULTURAL SCIENCE: LEUVEN 1, 2006; pp 227-231.

354. Zhebentyayeva, T.N.; Reighard, G.L.; Lalli, D.; Gorina, V.M.; Krska, B.; Abbott, A.G. Origin of resistance to plum pox virus in apricot: What new aflp and targeted ssr data analyses tell. Tree Genet. Genomes 2008, 4, 403-417.

355. Damsteegt, V.D. The versatility of prunus tomentosa as a bioindicator of viruses. In 17th international symposium on virus and virus-like diseases of temperate fruit crops: Fruit tree diseases, vols 1 and 2, 1998; pp 143-146.

356. Damsteegt, V.D.; Waterworth, H.E.; Mink, G.I.; Howell, W.E.; Levy, L. Prunus tomentosa as a diagnostic host for detection of plum pox virus and other prunus viruses. Plant Dis. 1997, 81, 329-332.

357. Dosba, F. Progress and prospects in stone fruit breeding. In Genetics and breeding of tree fruits and nuts, INTERNATIONAL SOCIETY HORTICULTURAL SCIENCE: LEUVEN 1, 2003; pp 35-43.

358. Barnavetro, I.; Gyorgy, B.; Schuster, V.; Varro, R. Use of peroxidase labeled antibodies for detection of plum pox virus. Acta Phyto. Acad. Sci. Hung. 1980, 15, 333-338.

359. Adams, A.N.; Guise, C.M.; Crossley, S.J. Plum pox virus detection in dormant plum trees by pcr and elisa. Plant Pathol. 1999, 48, 240-244.

360. Caglayan, K.; Sertkaya, G.; Ulubas, C.; Kolber, M.; Krizbai, L. Characterization of plum pox potyvirus (ppv) by das-elisa and $\mathrm{rt}-\mathrm{pcr} / \mathrm{rflp}$ analysis in turkey. In Proceedings of the xixth 
international symposium on virus and virus-like diseases of temperate fruit crops: Fruit tree diseases, 2004; pp 183-188.

361. Dovas, C.I.; Mamolos, A.P.; Katis, N.I. Fluctuations in concentration of two potyviruses in garlic during the growing period and sampling conditions for reliable detection by elisa. Ann. Appl. Biol. 2002, 140, 21-28.

362. Thomidis, T.; Karajiannis, I. Using elisa and pcr to test the potential for spread of plum pox virus by seeds of different stone fruit cultivars. N. Z. J. Crop Hortic. Sci. 2003, 31, 69-72.

363. Asensio, M.; Gorris, M.T.; Sanz, A.; Camarasa, E.; Perez, E.; Carbonell, E.A.; Cambra, M. Characterization and detection of plum pox virus using monoclonal antibodies. In Xvith international symposium on fruit tree virus diseases, 1995; pp 354-356.

364. Lopezmoya, J.J.; Sanz, A.; Cambra, M.; Gorris, M.T.; Anaya, C.; Miguet, J.G.; Cortes, E.; Lopezabella, D. Production and characterization of monoclonal-antibodies to plum pox virus and their use in differentiation of mediterranean isolates. Arch. Virol. 1994, 135, 293-304.

365. Orban, S.; Theilmann, J.; Rochon, D. Production of polyclonal antibodies for the detection of plum pox virus in leaf tissue by a modified das-elisa assay. Can. J. Plant Pathol.-Rev. Can. Phytopathol. 2007, 29, 86-86.

366. Richter, J.; Proll, E.; Rabenstein, F.; Stanarius, A. Serological detection of members of the potyviridae with polyclonal antisera. J. Phytopathol. 1994, 142, 11-18.

367. Hilgert, I.; Cikanek, D.; Kristofova, H.; Karesova, R.; Navratil, M. Monoclonal-antibodies suitable for plum pox virus determination. Hybridoma 1993, 12, 215-220.

368. Myrta, A.; Potere, O.; Boscia, D.; Candresse, T.; Cambra, M.; Savino, V. Production of a monoclonal antibody specific to the el amar strain of plum pox virus. Acta Virol. 1998, 42, 248250.

369. Cambra, M.; Asensio, M.; Gorris, M.T.; Pérez, E.; Camarasa, E.; Garcia, J.A.; Moya, J.J.; Lopez-Abella, D.; Vela, C.; Sanz, A. Detection of plum pox potyvirus using monoclonal antibodies to structural and non-structural proteins. EPPO Bull. 1994, 24, 569-577.

370. Martin, M.T.; Garcia, J.A.; Cervera, M.T.; Goldbach, R.W.; Vanlent, J.W.M. Intracellularlocalization of 3 nonstructural plum pox potyvirus proteins by immunogold labeling. Virus Res. 1992, 25, 201-211.

371. Purcifull, D.E.; Hiebert, E. Serological relationships involving potyviral nonstructural proteins. Arch. Virol. 1992, 97-122.

372. Ravelonandro, M.; Peyruchaud, O.; Garrigue, L.; Demarcillac, G.; Dunez, J. Immunodetection of the plum pox virus helper component in infected plants and expression of its gene in transgenic plants. Arch. Virol. 1993, 130, 251-268.

373. Gil, M.; Esteban, O.; Garcia, J.A.; Pena, L.; Cambra, M. Resistance to plum pox virus in plants expressing cytosolic and nuclear single-chain antibodies against the viral rna nib replicase. Plant Pathol. 2011, 60, 967-976.

374. Olmos, A.; Cambra, M.; Dasi, M.A.; Candresse, T.; Esteban, O.; Gorris, M.T.; Asensio, M. Simultaneous detection and typing of plum pox potyvirus (ppv) isolates by heminested-pcr and pcr-elisa. J. Virol. Methods 1997, 68, 127-137. 
375. Kamenova, I.; Peters, D. The differential reactivity of two polyclonal antisera to plum pox virus isolates collected at different stages after immunization. Biotechnol. Biotechnol. Equip. 1999, 13, 33-39.

376. Subr, Z.; Matisova, J. Preparation of diagnostic monoclonal antibodies against two potyviruses. Acta Virol. 1999, 43, 255-257.

377. Himmler, G.; Brix, U.; Steinkellner, H.; Laimer, M.; Mattanovich, D.; Katinger, H.W.D. Early screening for anti-plum pox virus monoclonal-antibodies with different epitope specificities by means of gold-labeled immunosorbent electron-microscopy. J. Virol. Methods 1988, 22, 351358.

378. Jarocka, U.; Wasowicz, M.; Radecka, H.; Malinowski, T.; Michalczuk, L.; Radecki, J. Impedimetric immunosensor for detection of plum pox virus in plant extracts. Electroanalysis 2011, 23, 2197-2204.

379. Pollini, C.P.; Giunchedi, L.; Bissani, R. Specific detection of $\mathrm{d}-$ and $\mathrm{m}$-isolates of plum pox virus by immunoenzymatic determination of pcr products. J. Virol. Methods 1997, 67, 127-133.

380. Youssef, S.A.; Shalaby, A.A.; Mazyad, H.M.; Hadidi, A. Detection and identification of prune dwarf virus and plum pox virus by standard and multiplex rt-pcr probe capture hybridization (rtpcr-elisa). J. Plant Pathol. 2002, 84, 113-119.

381. Wetzel, T.; Candresse, T.; Ravelonandro, M.; Delbos, R.P.; Mazyad, H.; Aboulata, A.E.; Dunez, J. Nucleotide-sequence of the 3'-terminal region of the rna of the elamar strain of plum pox potyvirus. Journal of General Virology 1991, 72, 1741-1746.

382. Wetzel, T.; Candresse, T.; Ravelonandro, M.; Dunez, J. A polymerase chain-reaction assay adapted to plum pox potyvirus detection. J. Virol. Methods 1991, 33, 355-365.

383. Subr, Z.; Glasa, M. Plum pox virus variability detected by the advanced analytical methods. Acta Virol. 2008, 52, 75-89.

384. Wetzel, T.; Tavert, G.; Teycheney, P.Y.; Ravelonandro, M.; Candresse, T.; Dunez, J. Dot hybridization detection of plum pox virus using p-32 labeled rna probes representing nonstructural viral protein genes. J. Virol. Methods 1990, 30, 161-171.

385. Varveri, C.; Candresse, T.; Cugusi, M.; Ravelonandro, M.; Dunez, J. Use of a p-32-labeled transcribed rna probe for dot hybridization detection of plum pox virus. Phytopathology 1988, $78,1280-1283$.

386. Hammond, J.; Puhringer, H.; Machado, A.D.; Machado, M.L.D. A broad-spectrum pcr assay combined with rflp analysis for detection and differentiation of plum pox virus isolates. In $17 \mathrm{th}$ international symposium on virus and virus-like diseases of temperate fruit crops: Fruit tree diseases, vols 1 and 2, INTERNATIONAL SOCIETY HORTICULTURAL SCIENCE: LEUVEN 1, 1998; pp 483-490.

387. Gadiou, S.; Safarova, D.; Navratil, M. Differentiation of plum pox virus isolates by single-strand conformation polymorphism and low-stringency single specific primer pcr analysis of hc-pro genome region. Acta Virol. 2009, 53, 53-56.

388. Subr, Z.; Pittnerova, S.; Glasa, M. A simplified rt-pcr-based detection of recombinant plum pox virus isolates. Acta Virol. 2004, 48, 173-176. 
389. Spiegel, S.; Kovalenko, E.M.; Varga, A.; James, D. Detection and partial molecular characterization of two plum pox virus isolates from plum and wild apricot in southeast kazakhstan. Plant Dis. 2004, 88, 973-979.

390. Szemes, M.; Kalman, M.; Myrta, A.; Boscia, D.; Nemeth, M.; Kolber, M.; Dorgai, L. Integrated $\mathrm{rt}-\mathrm{pcr} /$ nested per diagnosis for differentiating between subgroups of plum pox virus. J. Virol. Methods 2001, 92, 165-175.

391. Pasquini, G.; Barba, M.; Hadidi, A.; Faggioli, F.; Negri, R.; Sobol, I.; Tiberini, A.; Caglayan, K.; Mazyad, H.; Anfoka, G. et al. Oligonucleotide microarray-based detection and genotyping of plum pox virus. J. Virol. Methods 2008, 147, 118-126.

392. Olmos, A.; Bertolini, E.; Gil, M.; Cambra, M. Real-time assay for quantitative detection of nonpersistently transmitted plum pox virus rna targets in single aphids. J. Virol. Methods 2005, 128, 151-155.

393. Capote, N.; Gorris, M.T.; Martinez, M.C.; Asensio, M.; Olmos, A.; Cambra, M. Interference between $\mathrm{d}$ and $\mathrm{m}$ types of plum pox virus in japanese plum assessed by specific monoclonal antibodies and quantitative real-time reverse transcription-polymerase chain reaction. Phytopathology 2006, 96, 320-325.

394. Kim, W.S.; Stobbs, L.W.; Lehman, S.M.; James, D.; Svircev, A.M. Direct real-time pcr detection of plum pox virus in field surveys in ontario. Can. J. Plant Pathol.-Rev. Can. Phytopathol. 2008, 30, 308-317.

395. Capote, N.; Bertolini, E.; Olmos, A.; Vidal, E.; Martinez, M.C.; Cambra, M. Direct sample preparation methods for the detection of plum pox virus by real-time rt-pcr. Int. Microbiol. 2009, 12, 1-6.

396. Levy, L.; Kolber, M.; Tokes, G.; Nemeth, M.; Hadidi, A. 3' non-coding region rt-pcr detection and molecular hybridization of plum pox virus in anthers of infected stone fruit. In Xvith international symposium on fruit tree virus diseases, INTERNATIONAL SOCIETY HORTICULTURAL SCIENCE: LOUVAIN, 1995; pp 331-339.

397. Schneider, W.L.; Sherman, D.J.; Stone, A.L.; Damsteegt, V.D.; Frederick, R.D. Specific detection and quantification of plum pox virus by real-time fluorescent reverse transcription-pcr. J. Virol. Methods 2004, 120, 97-105.

398. Varga, A.; James, D. Real-time rt-pcr and sybr green $\mathrm{i}$ melting curve analysis for the identification of plum pox virus strains c, ea, and w: Effect of amplicon size, melt rate, and dye translocation. J. Virol. Methods 2006, 132, 146-153.

399. Varga, A.; James, D. Detection and differentiation of plum pox virus using real-time multiplex pcr with sybr green and melting curve analysis: A rapid method for strain typing. J. Virol. Methods 2005, 123, 213-220.

400. Korschineck, I.; Himmler, G.; Sagl, R.; Steinkellner, H.; Katinger, H.W.D. A pcr membrane spot assay for the detection of plum pox virus-rna in bark of infected trees. J. Virol. Methods 1991, $31,139-146$.

401. Olmos, A.; Bertolini, E.; Cambra, M. Simultaneous and co-operational amplification (co-pcr): A new concept for detection of plant viruses. J. Virol. Methods 2002, 106, 51-59. 
402. Bertolini, E.; Torres, E.; Olmos, A.; Martin, M.P.; Bertaccini, A.; Cambra, M. Co-operational pcr coupled with dot blot hybridization for detection and $16 \mathrm{srx}$ grouping of phytoplasmas. Plant Pathol. 2007, 56, 677-682.

403. Martos, S.; Torres, E.; El Bakali, M.A.; Raposo, R.; Gramaje, D.; Armengol, J.; Luque, J. Cooperational per coupled with dot blot hybridization for the detection of phaeomoniella chlamydospora on infected grapevine wood. J. Phytopathol. 2011, 159, 247-254.

404. Wetzel, T.; Candresse, T.; Macquaire, G.; Ravelonandro, M.; Dunez, J. A highly sensitive immunocapture polymerase chain-reaction method for plum pox potyvirus detection. J. Virol. Methods 1992, 39, 27-37.

405. Sreenivasulu, M.; Gopal, D. Development of recombinant coat protein antibody based ic-rt-pcr and comparison of its sensitivity with other immunoassays for the detection of papaya ringspot virus isolates from india, (vol 26, pg 25, 2010). Plant Pathol. J. 2010, 26, 207-+.

406. Sreenivasulu, M.; Gopal, D. Development of recombinant coat protein antibody based ic-rt-pcr and comparison of its sensitivity with other immunoassays for the detection of papaya ringspot virus isolates from india. Plant Pathol. J. 2010, 26, 25-31.

407. Huang, C.H.; Hu, W.C.; Yang, T.C.; Chang, Y.C. Zantedeschia mild mosaic virus, a new widespread virus in calla lily, detected by elisa, dot-blot hybridization and ic-rt-pcr. Plant Pathol. 2007, 56, 183-189.

408. Hema, M.; Kirthi, N.; Sreeivasulu, P.; Savithri, H.S. Development of recombinant coat protein antibody based ic-rt-pcr for detection and discrimination of sugarcane streak mosaic virus isolates from southern india. Arch. Virol. 2003, 148, 1185-1193.

409. Olmos, A.; Bertolini, E.; Cambra, M. Isothermal amplification coupled with rapid flow-through hybridisation for sensitive diagnosis of plum pox virus. J. Virol. Methods 2007, 139, 111-115.

410. Olmos, A.; Bertolini, E.; Cambra, M. Isothermal amplification for detection of plum pox virus. In Proceedings of the twentieth international symposium on virus and virus-like diseases of temperate fruit crops - fruit tree diseases, INTERNATIONAL SOCIETY HORTICULTURAL SCIENCE: LEUVEN 1, 2008; pp 209-213.

411. Hadersdorfer, J.; Neumuller, M.; Treutter, D.; Fischer, T.C. Fast and reliable detection of plum pox virus in woody host plants using the blue lamp protocol. Ann. Appl. Biol. 2011, 159, 456466.

412. Capote, N.; Bertolini, E.; Martinez, M.C.; Olmos, A.; Gorris, M.T.; Cambra, M. Spot real-time rt-pcr: A method for direct detection of plum pox virus avoiding rna extraction. In Proceedings of the twentieth international symposium on virus and virus-like diseases of temperate fruit crops - fruit tree diseases, INTERNATIONAL SOCIETY HORTICULTURAL SCIENCE: LEUVEN 1, 2008; pp 215-219.

413. Sanchez, F.; Sobolev, K. Nanotechnology in concrete - a review. Constr. Build. Mater. 2010, 24, 2060-2071.

414. Shea, C.M.; Grinde, R.; Elmslie, B. Nanotechnology as general-purpose technology: Empirical evidence and implications. Tech. Anal. Strat. Manag. 2011, 23, 175-192.

415. Banerjee, R.; Katsenovich, Y.; Lagos, L.; Mclintosh, M.; Zhang, X.; Li, C.Z. Nanomedicine: Magnetic nanoparticles and their biomedical applications. Curr. Med. Chem. 2010, 17, 31203141. 
416. Cai, S.; Yang, Q.H.; Bagby, T.R.; Forrest, M.L. Lymphatic drug delivery using engineered liposomes and solid lipid nanoparticles. Adv. Drug Deliv. Rev. 2011, 63, 901-908.

417. Feng, B.; Matsui, H.; Tomizawa, K. Nanoparticle-based drug delivery systems for solid brain tumors. Curr. Nanosci. 2011, 7, 47-54.

418. Ghaderi, S.; Ramesh, B.; Seifalian, A.M. Fluorescence nanoparticles "quantum dots" as drug delivery system and their toxicity: A review. J. Drug Target. 2011, 19, 475-486.

419. Chen, G.J.; Wang, L.F. Design of magnetic nanoparticles-assisted drug delivery system. Curr. Pharm. Design 2011, 17, 2331-2351.

420. Malam, Y.; Lim, E.J.; Seifalian, A.M. Current trends in the application of nanoparticles in drug delivery. Curr. Med. Chem. 2011, 18, 1067-1078.

421. Parveen, S.; Misra, R.; Sahoo, S.K. Nanoparticles: A boon to drug delivery, therapeutics, diagnostics and imaging. Nanomed.-Nanotechnol. Biol. Med. 2012, 8, 147-166.

422. Paulo, C.S.O.; das Neves, R.P.; Ferreira, L.S. Nanoparticles for intracellular-targeted drug delivery. Nanotechnology 2011, 22.

423. Prow, T.W.; Grice, J.E.; Lin, L.L.; Faye, R.; Butler, M.; Becker, W.; Wurm, E.M.T.; Yoong, C.; Robertson, T.A.; Soyer, H.P. et al. Nanoparticles and microparticles for skin drug delivery. Adv. Drug Deliv. Rev. 2011, 63, 470-491.

424. Su, X.; Zhan, X.; Tang, F.; Yao, J.Y.; Wu, J. Magnetic nanoparticles in brain disease diagnosis and targeting drug delivery. Curr. Nanosci. 2011, 7, 37-46.

425. Talekar, M.; Kendall, J.; Denny, W.; Garg, S. Targeting of nanoparticles in cancer: Drug delivery and diagnostics. Anti-Cancer Drugs 2011, 22, 949-962.

426. Yoo, J.W.; Doshi, N.; Mitragotri, S. Adaptive micro and nanoparticles: Temporal control over carrier properties to facilitate drug delivery. Adv. Drug Deliv. Rev. 2011, 63, 1247-1256.

427. Eggenberger, K.; Frey, N.; Zienicke, B.; Siebenbrock, J.; Schunck, T.; Fischer, R.; Brase, S.; Birtalan, E.; Nann, T.; Nick, P. Use of nanoparticles to study and manipulate plant cells. Adv. Eng. Mater. 2010, 12, B406-B412.

428. Baruah, S.; Dutta, J. Nanotechnology applications in pollution sensing and degradation in agriculture: A review. Environ. Chem. Lett. 2009, 7, 191-204.

429. Knauer, K.; Bucheli, T. Nano-materials - the need for research in agriculture. Agrarforschung 2009, 16, 390-395.

430. Knauer, K.; Bucheli, T.D. Nano-materials: Research needs in agriculture. Rev. Suisse Agric. 2009, 41, 341-345.

431. Shrivastava, S.; Dash, D. Agrifood nanotechnology: A tiny revolution in food and agriculture. $J$. Nano Res. 2009, 6, 1-14.

432. Lokko, Y.; Mba, C.; Spencer, M.; Till, B.; Lagoda, P. Nanotechnology and synthetic biology potential in crop improvement. J. Food Agric. Environ. 2011, 9, 599-604.

433. Young, M.; Willits, D.; Uchida, M.; Douglas, T. Plant viruses as biotemplates for materials and their use in nanotechnology. In Annu. Rev. Phytopathol. 2008; pp 361-384.

434. Aniagyei, S.E.; DuFort, C.; Kao, C.C.; Dragnea, B. Self-assembly approaches to nanomaterial encapsulation in viral protein cages. J. Mater. Chem. 2008, 18, 3763-3774.

435. Srivastava, S.K. Use of plant viruses and their genes in the areas of biotechnology and nanotechnology. Indian J. Virol. 2008, 19, 101-102. 
436. Behrens, S.S. Synthesis of inorganic nanomaterials mediated by protein assemblies. J. Mater. Chem. 2008, 18, 3788-3798.

437. Lee, S.Y.; Lim, J.S.; Harris, M.T. Synthesis and application of virus-based hybrid nanomaterials. Biotechnol. Bioeng. 2012, 109, 16-30.

438. Royston, E.; Ghosh, A.; Kofinas, P.; Harris, M.T.; Culver, J.N. Self-assembly of virusstructured high surface area nanomaterials and their application as battery electrodes. Langmuir 2008, 24, 906-912.

439. Soto, C.M.; Ratna, B.R. Virus hybrids as nanomaterials for biotechnology. Curr. Opin. Biotechnol. 2010, 21, 426-438.

440. Zhou, Y. Recent progress in biomolecule-templated nanomaterials. Curr. Nanosci. 2006, 2, $123-$ 134.

441. Flenniken, M.L.; Uchida, M.; Liepold, L.O.; Kang, S.; Young, M.J.; Douglas, T. A library of protein cage architectures as nanomaterials. In Viruses and nanotechnology, 2009; pp 71-93.

442. Franzen, S.; Lockney, D.M.; Wang, R.Q.; Lommel, S.; Hauck, M. In vivo imaging and tumor targeting using a plant virus nanoparticle. Abstr. Pap. Am. Chem. Soc. 2011, 241.

443. Lockney, D.M.; Guenther, R.N.; Loo, L.; Overton, W.; Antonelli, R.; Clark, J.; Hu, M.; Luft, C.; Lommel, S.A.; Franzen, S. The red clover necrotic mosaic virus capsid as a multifunctional cell targeting plant viral nanoparticle. Bioconjugate Chem. 2011, 22, 67-73.

444. Liang, M.M.; Guo, L.H. Application of nanomaterials in environmental analysis and monitoring. J. Nanosci. Nanotechnol. 2009, 9, 2283-2289.

445. Martin, C.R. Nanomaterials: Evolving applications in membranes, energy production, and analytical chemistry. Abstr. Pap. Am. Chem. Soc. 2000, 219, U727-U727.

446. Martin, C.R.; Mitchell, D.T. Nanomaterials in analytical chemistry. Anal. Chem. 1998, 70, 322A-327A.

447. Scida, K.; Stege, P.W.; Haby, G.; Messina, G.A.; Garcia, C.D. Recent applications of carbonbased nanomaterials in analytical chemistry: Critical review. Anal. Chim. Acta 2011, 691, 6-17.

448. Valentini, F.; Palleschi, G. Nanomaterials and analytical chemistry. Anal. Lett. 2008, 41, 479520.

449. Bandyopadhyay, A.; Chatterjee, S.; Sarkar, K. Rapid isolation of genomic DNA from e. Coli x11 blue strain approaching bare magnetic nanoparticles. Curr. Sci. 2011, 101, 210-214.

450. Chiang, C.L.; Sung, C.S.; Chen, C.Y. Application of silica-magnetite nanocomposites to the isolation of ultrapure plasmid DNA from bacterial cells. J. Magn. Magn. Mater. 2006, 305, 483490.

451. Sarkar, T.R.; Irudayaraj, J. Carboxyl-coated magnetic nanoparticles for mrna isolation and extraction of supercoiled plasmid DNA. Anal. Biochem. 2008, 379, 130-132.

452. Zhang, H.P.; Bai, S.; Xu, L.; Sun, Y. Fabrication of mono-sized magnetic anion exchange beads for plasmid DNA purification. J. Chromatogr. B 2009, 877, 127-133.

453. Masarik, M.; Gumulec, J.; Sztalmachova, M.; Hlavna, M.; Babula, P.; Krizkova, S.; Ryvolova, M.; Jurajda, M.; Sochor, J.; Adam, V. et al. Isolation of metallothionein from cells derived from aggressive form of high-grade prostate carcinoma using paramagnetic antibody-modified microbeads off-line coupled with electrochemical and electrophoretic analysis. Electrophoresis 2011, 32, 3576-3588. 
454. Adam, V.; Huska, D.; Hubalek, J.; Kizek, R. Easy to use and rapid isolation and detection of a viral nucleic acid by using paramagnetic microparticles and carbon nanotubes-based screenprinted electrodes. Microfluid. Nanofluid. 2010, 8, 329-339.

455. Huska, D.; Hubalek, J.; Adam, V.; Vajtr, D.; Horna, A.; Trnkova, L.; Havel, L.; Kizek, R. Automated nucleic acids isolation using paramagnetic microparticles coupled with electrochemical detection. Talanta 2009, 79, 402-411.

456. Masarik, M.; Huska, D.; Adam, V.; Hubalek, J.; Provaznik, I.; Trnkova, L.; Kizek, R. Automated pipetting system coupled with micro- and nanopartieles as a new tool for study of nucleic acids. Int. J. Mol. Med. 2010, 26, S46-S46.

457. Wang, J.; Hui, F.; Fang, X.W.; Vinciguerra, J.; Hunicke-Smith, S.; WalkerPeach, C.R. Magnetic bead-based viral nucleic acid isolation incorporating a quantitative internal control. J. Mol. Diagn. 2004, 6, 427-427.

458. Zhang, Z.C.; Cui, Y.; Wan, Q.H. Surface modification of magnetic silica microspheres and its application to the isolation of plant genomic nucleic acids. Chin. J. Anal. Chem. 2007, 35, 31-36.

459. Miszczak, F.; Shuck, K.M.; Lu, Z.C.; Go, Y.Y.; Zhang, J.Q.; Sells, S.; Vabret, A.; Pronost, S.; Fortier, G.; Timoney, P.J. et al. Evaluation of two magnetic-bead-based viral nucleic acid purification kits and three real-time reverse transcription-pcr reagent systems in two taqman assays for equine arteritis virus detection in semen. J. Clin. Microbiol. 2011, 49, 3694-3696.

460. Sun, H.X.; Zeng, X.; Liu, M.; Elingarami, S.; Li, G.P.; Shen, B.; He, N.Y. Synthesis of sizecontrolled fe3o4@sio2 magnetic nanoparticles for nucleic acid analysis. J. Nanosci. Nanotechnol. 2012, 12, 267-273.

461. Yang, S.Y.; Chieh, J.J.; Wang, W.C.; Yu, C.Y.; Hing, N.S.; Horng, H.E.; Hong, C.Y.; Yang, H.C.; Chang, C.F.; Lin, H.Y. Magnetic nanoparticles for high-sensitivity detection on nucleic acids via superconducting-quantum-interference-device-based immunomagnetic reduction assay. J. Magn. Magn. Mater. 2011, 323, 681-685.

462. Byzova, N.A.; Safenkova, I.V.; Chirkov, S.N.; Avdienko, V.G.; Guseva, A.N.; Mitrofanova, I.V.; Zherdev, A.V.; Dzantiev, B.B.; Atabekov, J.G. Interaction of plum pox virus with specific colloidal gold-labeled antibodies and development of immunochromatographic assay of the virus. Biochem.-Moscow 2010, 75, 1393-1403.

463. Safenkova, I.V.; Zherdev, A.V.; Dzantiev, B.B. Correlation between the composition of multivalent antibody conjugates with colloidal gold nanoparticles and their affinity. J. Immunol. Methods 2010, 357, 17-25.

(C) 2012 by the authors; licensee MDPI, Basel, Switzerland. This article is an open access article distributed under the terms and conditions of the Creative Commons Attribution license (http://creativecommons.org/licenses/by/3.0/). 